\title{
Flora and vegetation of some coastal ecosystems of Sterea Ellas and eastern continental Greece
}

\author{
Maria Sarika (*)
}

\begin{abstract}
Sarika, M. Notes on the flora and vegetation of some coastal ecosystems of Sterea Ellas and eastern continental Greece (Greece). Lazaroa 33: 65-99 (2012).

Vegetation of four coastal ecosystems of eastern continental Greece and of Sterea Ellas, including dune, marshland, wet meadow, reed bed and aquatic habitats, was studied in several years. The flora of the investigated regions consists of 217 taxa belonging to 42 families and 135 genera, most of which are reported for the first time. The majority of taxa are Therophytes (101 taxa, 46\%); Hemicryptophytes and Geophytes are also well represented in the life form spectrum. From a chorological point of view the Mediterranean element (123 taxa, 57\%) outweight the rest while the most diverse group of widespread taxa occupies the second place (83 taxa, 38\%). The macrophytic vegetation was analysed following the Braun-Blanquet method. Twenty one plant communities were found belonging to twelve alliances, ten orders and eight phytosociological classes. The vegetation units distinguished are described, documented in form of phytosociological tables, and compared with similar communities from other Mediterranean countries. According to directive 92/43/EU, nine habitat types were delimited through the assessment of the dominant vegetation types.
\end{abstract}

Keywords: flora, vegetation, coastal ecosystems, habitat types, Greece.

Resumen: Sarika, M. Flora y vegetación de los ecosistemas costeros de Sterea Ellas y del este de la Grecia continental. Lazaroa 33: 65-99 (2012).

La vegetación de cuatro áreas de costa del este de Grecia continental y de Sterea Ellas ha sido estudiada en distintas campañas. Estos estudios incluyen dunas, marjales, prados húmedos, cañaverales y comunidades acuáticas. La flora de los territorios estudiados se compone de 217 taxones, pertenecientes a 42 familias y 135 géneros, la mayor parte de los cuales están citados por primera vez. La mayoría de ellos son terófitos $(46 \%, 101$ especies), mientras que los hemicriptófitos y los geófitos también están bien representados. Desde el punto de vista corológico los elementos mediterráneos $(57 \%, 123$ especies) suponen el mayor contingente, mientras que lase species ampliamente distribuidos suponen el $38 \%$ ( 83 especies). La vegetación macrofítica fue analizada por el método sigmatista de Braun-Blanquet. Veintidos comunidades fueron detectadas y agrupadas en doce alianzas, diez órdenes y ocho clases fitosociológicas. De todas ellas, aportamos documentación y tablas fitosociológicas y se han comparado con otros tipos de vegetación similar de otros países mediterráneos. De acuerdo a la Directiva 92/43/EU, se han reconocido nueve tipos de hábitats a través del estudio de los tipos de vegetación dominantes.

Palabras clave: flora, vegetación, ecosistemas costeros, habitats, Grecia.

\section{INTRODUCTION}

Coastal ecosystems are among the most productive and the most heavily used and threatened natural systems globally. Their deterioration due to human activities is intense and increasing. Nevertheless, they support a broad range of habitat types that contain a wealth of species and genetic diversity, they store and cycle nutrients, filter pollutants from inland freshwater systems, and help to protect shorelines from erosion and storms. Coastal regions include a wide array of near shore-terrestrial (dunes and sandy shores), and intertidal (estuaries, deltas, lagoons) environments, each of which provides its own distinct bundle of goods and services and faces somewhat different pressures.

In these ecosystems, the distribution pattern of plant communities is related to substrate proper-

* Institute of Systematic Botany, Section of Ecology and Systematics. Department of Biology. University of Athens. GR-15784 Athens, Greece. E-mail: msarika@biol.uoa.gr 
ties such as soil salinity and moisture - both widely recognised as the most important factors that are controlled by temporary salt-water flooding. These properties determine the occurrence of two main types of coastal vegetation: plant communities in dune and sandy shore environments, and plant communities in maritime wetlands which are essentially able to grow on flooded and saline soils (RIVAS-MARTínEZ \& al., 1980). The latter are arranged along a hygro-halophilous gradient. The muddy zones that are flooded or are directly influenced by seawater (mudflats, salt marshes), are vegetated by annual or perennial species with fleshy leaves or stems, able to withstand inundation and intense evaporation. The influence of tides on coastal vegetation depends on the relative duration of submergence and exposure, and the duration of this period is critical to the establishment of plant from seed, especially for annual plants such as Salicornia (CUTINI \& al., 2010). Further inland, the vegetation of salt meadows and brackish reed beds is usually more diverse and composed of various communities characterised by rushes and tall helophytes (MolinA, 1994, 1996; CuRCó, 2001; Molina \& al., 2003). Coastal wetlands are regarded as transitional ecosystems regulating fluxes of materials and energy between the land and the sea. They are increasingly becoming the last remaining coastal biodiversity hot spots worldwide, as refuges for wildlife faced with the human squeeze (DE LAS Heras \& al., 2009; Perillo \& al., 2009).

The Greek coastal ecosystems have attracted the interest of botanists during past decades, and several publications concerning their vascular flora and vegetation are available. The most recent related research projects were carried out in Macedonia (BABAlONAS \& PAPASTERgiadou, 1993; KARAGIANNAKIDOU \& al., 2000; VASILIOU \& al., 2000), Thrace (Drossos, 1992), Thessaly (Drossos \& al., 1996; Eleftheriadou \& al., 1995), western Greece (GEORGIADIS \& al., 1990, 1997; KoumPli-Sovantzi, 1991, 2005; RaABE \& KOUMPLI-SOVANTZI, 2000; SARIKA \& al., 2005; Christia \& PAPASTERgiadou, 2007; KARAGianNI \& al., 2008; Christia \& al., 2011) and Peloponnese (KoRAKIS \& GERASIMIDIS, 2006). Data on Northern Aegean coastal habitats (PAPASTERGIA-
DOU \& BABALONAS, 1996) as well as some reviews of the Greek coastal flora and vegetation have also been published (LAVRENTIADES, 1993; BABALONAS \& al., 1995; SÝKORA \& al., 2003).

The flora and vegetation of near shore-terrestrial and wetland environments encountered in four coastal ecosystems in the eastern part of central Greece and of Sterea Ellas are the subject of this study. The investigated regions involve (1) a coastal ecosystem near the village of Sourpi (Pagasitikos Gulf, Magnissia Prefecture) called Elos Sourpis, (2) the Spercheios River Delta near the city of Lamia (Maliakos Gulf, Phthiotida Prefecture), (3) coastal area near the village of Scala Atalantis (Northern Evoikos Gulf, Phthiotida Prefecture) called Vourlias wetland, and (4) coastal area in the northern part of the Attiki Prefecture between Chalkutsi and Oropos villages (Southern Evoikos Gulf). Apart from some species reported from the coastal wetlands of Oropos (Koumpli-SovantZi \& VAlliaNATOU, 1994; KouMPLI-SOVANTZI, 1995), there are no floristic or phytosociological reports from these regions.

This paper aims to provide the first inventory of the flora, vegetation and habitat types encountered in the abovementioned natural ecosystems and regions.

\section{STUDY AREA}

\section{LOCATIONS AND GEOLOGY}

The wetland Elos Sourpis is a coastal ecosystem (28 ha) of eastern continental Greece located between Platanos and Sourpi villages in the Pagasitikos Gulf (E 22 $50^{\circ} 00^{\prime \prime} N 39^{\circ} 10^{\prime} 0$ ") (Figure 1). It mainly consists of seasonally inundated mudflats, salt meadows, reed beds and Tamarix $s p$. A stream with intermittent flow crossing the area and a spring close to its upland border supply the wetland with fresh water. Seawater flows into the marsh, making the water brackish to saline. Middle Triassic to Jurassic marble forms the alpine geological substratum, outcropping on the southern part of the Sourpi Bay. Eastward of these formations appears the late Cretaceous flysch, namely phyllites and sandstones, with grey limes- 


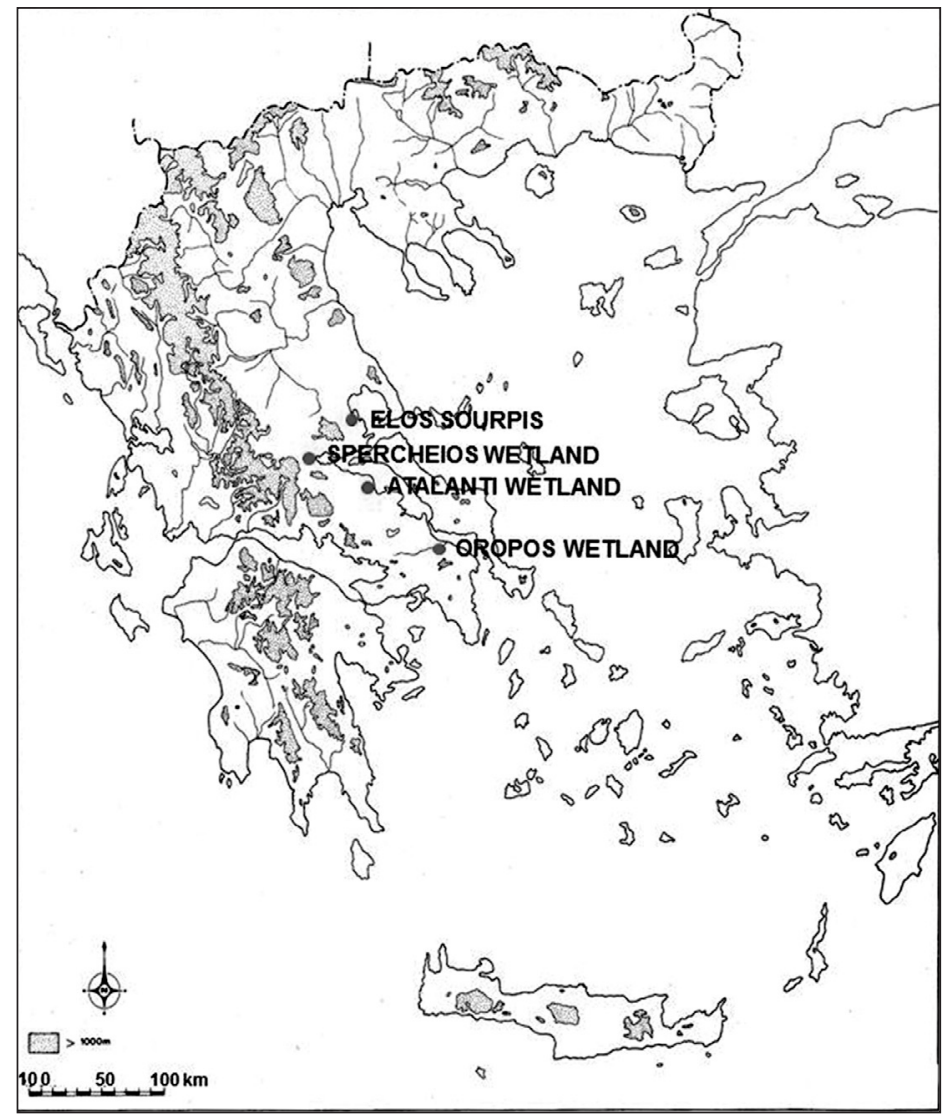

Figure 1. - Map of Greece showing the location of the four studied coastal regions.

tone intercalations. Quaternary alluvial clastic sediments, derived from the continental erosion and re-deposition of the above deposits, cover the alpine formations on the north-northwestern part of Sourpi, and are also found in coastal marine deposition of silts, sands and conglomerates (MARINOS \& al., 1962).

The Spercheios River meets the sea at the eastern part of central Greece, in the southwest corner of the Maliakos Gulf (E 22³4'32" N 38'50'26") (Figure 1), where it forms an extensive outfall area that comprises floodplains, mudflats, salt marshes, reed beds and inlets of particular importance for many birds. This coastal estuarine system is included in the Special Protection Areas for avifauna and the Sites of Community Importance, as defined in directives 79/409/EEC and 92/43/EEC respectively. The core of the estuary covers 3966,38 ha while the wider area is close to 10000 ha. Most of the area outside the core is intensively cultivated - mainly as rice fields. The land around the estuary is occupied mainly by dry cropland and grasslands, while a small portion is covered by olive trees. Quaternary fluvial deposits cover the entire area of the Spercheios River Delta, in addition to coastal marine conglomerates. Erosion material (marls, silts, sandstones, conglomerates) originating from Neogene deposits lies to the west and southwest of the area. The Neogene deposits, with lignite horizons, contain lake invertebrate fossils, such as Limnaea, Pianorbis, Melanopsis, and Vivapara. Coastal marine Neogene sediments also outcrop in the area and contain fossil bivalves, such as Ostrea and Cardium (MARINOS \& al., 1963).

The Atalanti or Vourlias wetland is located near to the village of Scala Atalantis in the Northern Evoikos Gulf (E 235'0" N 38 35'0") (Figure 1). It comprises a narrow coastal zone with mudflats, salt marshes, degraded wetland vegeta- 
tion, agricultural land, and shallow inlets. The geological setting of the area consists of Quaternary clastic deposits (clays, sands, gravel, talus). These are mainly continental deposits originating from erosion and deposition of the substratum, which is exposed on the topographic highs further to west. Coastal conglomerate deposits have developed occasionally. Limestone formations appear mainly to the south (MARATOS, 1965).

The wetland area lying in the northern part of the Attiki Prefecture between the villages of Chalkutsi and Scala of Oropos (E 23⒋ $3^{\circ}$ " N $38^{\circ} 20^{\prime} 0^{\prime \prime}$ ) (Figure 1) is delimited on its western side by the Asopos River estuary and covers 420 ha. Its eastern boundaries are designated by a complex system of sand and mudflats seasonally inundated by seawater, forming lagoons and changing the landscape of sea-inlets. Its central part was a salt marsh formation that has recently been departmentalised by buildings and roads. The deltaic geological deposits that cover the wetland area of Oropos consist of alluvial sands and silts, with a few conglomerates and red silts. These were deposited in old-river valleys, across a lowland area open to the sea. The coasts of the area expose sand and silty lacustrine and riverine deposits, and beach rocks. During the most recent geological times, these Holocene deposits represent the evolution of the Asopos Delta, as the river transported and deposited sedimentary material further seawards, extending the coastal area towards the sea (KATSIKATSOS, 2000; PARginOs \& al., 2007).

The ecosystems we investigated are important sites for the maintenance of local and regional biodiversity. They hold various types of habitat and vegetation, offering ideal environments for many species of avifauna. They are intermediate resting stations for migrating and wintering birds and they also sustain endemic or protected species such as Barbus cyclolepis cholorematicus Stephanidis, a fish endemic to the Cholorema stream that flows near the upland border of the Elos Sourpis wetland. Likewise, the temporary or permanent shallow brackish waters encountered in many habitat types of these ecosystems represent natural parks for the reproduction of fish and the development of their juveniles.

\section{Climate}

According to the xerothermic index (x) (BAGNOULS \& GAUSSEN, 1953), and based on climatic data from the meteorological stations of Volos (alt. $14.62 \mathrm{~m}$, period 1956-1997), Lamia (alt. $143.4 \mathrm{~m}$, period 1970-1997) and Tanagra (139 m, period 1958-2010), the climate of the regions can be characterised as meso-Mediterranean, intensely so in Tanagra (late April to early September, 68.69 biologically dry days) and weakly in the districts of Volos (late April to August, 48.45 biologically dry days) and Lamia (May to August, 45.53 biologically dry days). The xerothermic index reflects the intensity of dry period in a given region and represents the total number of biologically dry days of the dry months which are defined by the ombrothermic diagram of this region. For calculation of biologically dry days of each dry month a mathematical formula is used taking into account 1) the total number of days per dry month 2) the total number of rainy days per dry monh 3) the total number with dew per dry month and 4) the relative humidity coefficient. Based on EMBERGER's $(1955,1959)$ and SAUVAGE's (1963) climatic classifications, the meteorological station of Lamia belongs to the sub-humid bioclimatic zone, the meteorological station of Volos to the semi-arid bioclimatic zone, and the meteorological station of Tanagra to the arid bioclimatic zone.

\section{DATA AND METHODS}

The floristic and habitat records are based on data collected by the author during the spring and summer of 1999-2001, partly within the framework of the Natura 2000 Vegetation and Habitat Identification and Mapping project. For the study of the flora, 476 plant specimens were collected and identified in the Laboratory of Systematic Botany, University of Athens (ATHU). The nomenclature of taxa follows mainly GREUTER \& al. (1984, 1986, 1989, 2008), TuTin \& al. (1968$1980,1993)$ and STRID \& KIT TAN $(1997,2002)$. Life-form classification followed RAUNKIAER'S (1934) system improved by ELLENBERG and MüE- 
LLER-DOMBOIS (1967) and was based on the works of GARCKE \& Von WeiHe (1972), PignatTI (1982) and OBERDORFER (1990). For the chorological types, PIGNATTI's (1982) classification was used in combination with that of TUTIN \& al. (1968-1980, 1993).

For the identification and description of the prevailing vegetation types, 141 relevés (vegetation sample plots) were analysed in the field according to the BRAUN-BLANQUET method (Westhoff \& VAN DeR MaArel 1980; Kent \& COKER, 1992). The cover-abundance degree was estimated using the extended (9-point) BRAUNBLANQUET scale (BARKMAN \& al., 1964). The collection of vegetation samples was followed by a synthetic phase, leading to the distinction of the community types and their final classification into higher syntaxonomic units. At this stage the relevés were clustered into a "primary" or "raw" table in which the species were listed after their degree of presence. The primary table was rearranged several times, according to the table technique elaboration proposed by Knapp (1958) and Ellenberg (1956), in order to establish groupings of relevés by rearrangment of columns as well as to group taxa with similar distributions in the table by rearrangement of rows. The result of the first rearrangement of the primary table was the "presence table" in which became apparent, whether the relevés vary irregularly, or certain combinations of species prefer some relevés. Such groups of species were more or less mutually exclusive and were used as groups of differential species (provisional sets of diagnostic species) for further rearrangement of the presence table (Tables 2-10). In a next stage the differentiating species were grouped on the left hand side of the paper, the rows were arranged in their corresponding groups and the relevés were rearranged to show a diagonal order of species from the left to the right of the table. After a complete elaboration this table is a "differentiated table" in which the groups of differentiating species that correspond to the phytocoena included in the table appear clearly. The next step comprises the replacement of each relevé group (phytocoenon) distinguished on the basis of a specific group of differential species, by a column in which for each participating species the presence degree is indicated as a constancy class value. The table derived from this step of elaboration is called "synoptic table' (Tables $11,12)$ and after its comparison with tables from other types of vegetation of the same or adjacent regions an idea was formed about the local diagnostic species groups (character-species, differential species, constant companions). With those species the vegetation units (phytocoena) were then identified. Afterwards the synoptic tables were compared with literature and with tables with similar vegetation types from other regions. Character-taxa were found and a syntaxonomic interpretation was attempted. Vegetation units were delimited based on an assessment of species fidelity and are given in phytosociological tables (Tables 2-10). Syntaxonomic nomenclature is mainly based on PHILIPPI (1992), BALÁTOVÁ- OULÁČKOVĂ \& al. (1993), Mucina (1997), Rivas-MarTíNEZ \& al. (2001), SÝKORA \& al. (2003), and DÍEZ-GARRETAS \& al. (2003).

The delimitation and classification of habitats were achieved through the assessment of the dominant vegetation types and their characteristic and diagnostic species, as described in LAVRENTIADES $(1964,1971)$, HORVAT \& al. (1974), BABALONAS (1979), DimOPOULOS \& al. (1995), and SÝKORA \& al. (2003). The coding of the discernible habitats follows DAFIS \& al. $(1999,2001)$ and the INTERPRETATION MaNUal of EU Habitat TYPES (2003).

\section{RESULTS AND DISCUSSION}

\section{FLORA}

The vascular flora of the investigated coastal ecosystems includes 217 taxa (181 species, 36 subspecies) of 135 genera and 42 families. Apart from a few species already recorded from the Oropos coastal wetland area (KouMPLI-SovANTZI \& VAllianatou, 1994; KoumPli-SovantZi, 1995) the remainder are new for the investigated habitats. Among the families identified Graminae were the most diverse in species (53 taxa), followed by Compositae (19 taxa), Leguminosae (17 taxa), Chenopodiaceae (13 taxa) and Cyperaceae (13 
taxa). Of the plant species found in the areas of study only one is pteridophyte while the rest are all Spermatophytes (Dicotyledons 130 taxa, Monocotyledons 86 taxa). From all the plant taxa encountered we wish to emphasize the presence of Althenia filiformis and Bolanthus thymifolius.

Althenia filiformis is a Mediterranean element that prefers brackish water. It usually colonizes sites with direct or indirect contact with the sea, but is also encountered in inland salt lakes. It usually grows in water up to $50 \mathrm{~cm}$ deep, but in our case it was mostly found in $<10 \mathrm{~cm}$ of water at the edge of a small lagoon that lies at the southern end of the Oropos wetland area. It was either the only phanerophyte in the water or shared the habitat with Ruppia maritima. KouMPLI-SovANTZI (1995) reported A. filiformis from a vernal pool in the neighbourhood of the village of Oropos and from coastal aquatic habitats of Naxos island. These are the only records of this species from Greece.

The Greek endemic species Bolanthus thymifolius was found on sandy soil at the mouth of Spercheios River. This species is scattered from Strerea Ellas and Evvia to NE Greece, in rocky places, usually on limestone (STRID \& KIT TAN, 1997). According to TRIGAS (2003) it is mainly distributed in eastern Sterea Ellas and eastern Thessaly, sporadically occurring in Evvia and in northern Greece.

The life form spectrum in Figure 2 shows that in the investigated areas the proportion of Therophytes (101 taxa) is higher than that of other life forms. Hemicryptophytes (62 taxa) and Ge- ophytes (23 taxa) are also quite well represented, whereas Chamaephytes (12 taxa), Phanerophytes (9 taxa) and Hydrophytes (11 taxa) occur in lower percentages. According to data in the literature Therophytes almost always predominate in $\mathrm{Me}$ diterranean coastal ecosystems (GARCíA \& al., 1993), while a significant percentage of hemicryptophytes is usually observed when maritime wetlands are present in these ecosystems, due to the humid conditions that prevail in such habitats (BABALONAS, 1979; GEORGIADIS \& al. 1997; KORAKIS \& GERASIMIDIS, 2006). The chorological spectrum (Fig. 2) reveals a definite predominance of the Mediterranean element (60\%) that represent the largest group, including 132 taxa of which $74(34 \%)$ are Mediterranean (Medit., StenoMedit, Medit.-Atl., Medit.-Turan.) and 57 (26\%) Euro-Mediterranean. The group of widespread taxa, although comprising a greater number of geoelements (Paleotemperate, Subcosmopolitan, Cosmopolitan, European, Eurasiatic, Circumboreal, Paleosubtropical, Subtropical, Eurosiberian and Thermo-cosmopolitan), is in second place and is represented by just 86 taxa (39\%). Finally the Greek endemic element, makes up only a small percentage $(0,45 \%, 1$ taxon) of the chorological spectrum of the ecosystems studied.

The number of taxa found in the areas of study is rather low, if we take into account data concerning other coastal areas of Greece (GEORGIADIS \& $a l ., 1997$; SARIKA \& al., 2005), but it is widely accepted that in coastal wetlands a negative rela-

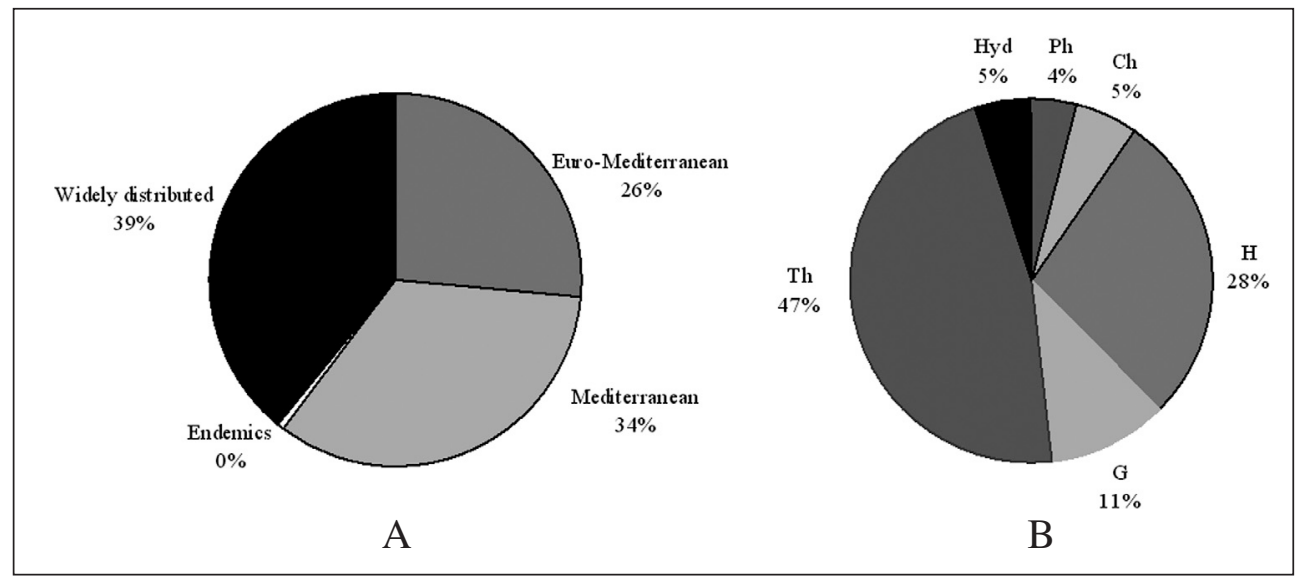

Figure 2. - Chorological spectrum (A) and life-form spectrum (B) of the investigated coastal flora. 
tionship exists between plant species richness and salinity. In fact, there is evidence in the literature to confirm that only relatively few plant species are able to tolerate a high salt concentration in the soil solution (GARCíA \& al., 1993; MEDINSKI, 2007; Perelman \& al., 2007). In the wetlands of Oropos we recorded 78 taxa; in the Atalanti wetland 71 taxa; in Elos Sourpis 80 taxa and in the Spercheios River Delta 111 taxa (see Appendix 1).

\section{VEGETATION AND HABITAT TYPES}

From the elaboration of data collected during the vegetation analysis in the field, a total of 6 associations, 2 subassociations and 13 communities not assigned formal rank were recognised (see symta- xonomical scheme). Classification of the distinguished vegetation units into habitat types according to directive 92/43/EU revealed nine habitat types that are strictly related to the soil humidity, salinity and texture (Table 1). A mosaic of plant communities, alternately distributed, was observed in all the investigated ecosystems, but the dominant vegetation units varied substantially among them. Thus, in the Spercheios River Delta, the communities of sandy soils, mudflats, salt meadows and reed beds are dominating the vegetation physiognomy. In the Elos Sourpis and in Atalanti wetlands the salt meadow and reed bed communities outweight the rest, whereas communities of Mediterranean and thermo-Atlantic halophilous scrubs dominate in the Oropos wetland area (Table 1).

\section{Table 1}

Classification of the distinguished vegetation units into habitat types according to directive 92/443/EU. Abbreviations are: Sp (Spercheios River Delta), Sr (Elos Sourpis), At (Atalanti wetland), and Or (Oropos wetlands)

\begin{tabular}{|c|c|c|c|c|}
\hline Habitat types and vegetation units & $\mathrm{Sp}$ & $\mathrm{Sr}$ & At & Or \\
\hline \multicolumn{5}{|l|}{ Annual vegetation of drift lines (1210) } \\
\hline Salsolo kali-Cakiletum maritimae & + & & + & \\
\hline \multicolumn{5}{|l|}{ Embryonic shifting dunes (2110) } \\
\hline Eryngio-Sporoboletum virginici & + & & + & \\
\hline \multicolumn{5}{|l|}{ Malcolmietalia dune grasslands (2230) } \\
\hline Aeluropus littoralis community & + & + & & + \\
\hline Matthiola tricuspidata-Anthemis tomentosa community & + & & & + \\
\hline \multicolumn{5}{|c|}{ Salicornia and other annuals colonising mud and sand (Thero-Salicornietea, 1310) } \\
\hline Spergularia salina-Salicornia europaea community & + & + & + & \\
\hline Spergularia salina-Suaeda splendens community & + & & & \\
\hline \multicolumn{5}{|c|}{ Mediterranean and thermo-Atlantic halophilous scrubs (Salicornietea fruticosae, 1420) } \\
\hline Sarcocornia perennis-Halimione portulacoides community & + & + & + & + \\
\hline Arthrocnemum macrostachyum community & + & & & + \\
\hline Sarcocornia fruticosa-Halocnemum strobilaceum community & & & & + \\
\hline Limonium gmelinii community & + & & & \\
\hline Limonium virgatum community & + & + & & \\
\hline \multicolumn{5}{|l|}{ Mediterranean salt meadows (1410) } \\
\hline Juncetum maritimo-acuti & + & + & + & + \\
\hline Juncus subulatus community & + & + & + & \\
\hline Juncus heldreichianus community & & + & + & \\
\hline Carex divisa-Carex distans community & & & + & \\
\hline \multicolumn{5}{|l|}{ Reed beds (72A0) } \\
\hline Phragmitetum communis typicum & + & + & + & \\
\hline Phragmitetum communis elymetosum elongati & + & + & & + \\
\hline Phragmitetum communis juncetosum subulati & + & + & + & \\
\hline Bolboschoenetum maritimi & + & + & + & \\
\hline \multicolumn{5}{|l|}{ Schoenoplectetum tabernaemontani } \\
\hline \multicolumn{5}{|c|}{ Natural eutrophic lakes with Magnopotamion or Hydrocharition-type vegetation (3150) } \\
\hline Potamogeton pectinatus-Myriophyllum spicatum community & & + & & \\
\hline Thermo-Mediterranean riparian galleries (92D0) & & + & & \\
\hline
\end{tabular}


Annual vegetation of drift lines (habitat code: 1210)

The salt-resistant shout-lived communities of the drift line (a narrow habitat strip at the high tidal mark characterized by accumulation of debris) are grouped within the Cakiletea maritimae. The Cakiletea communities form an ecotone between the beach and the adjacent dune ecosystem. This habitat type of drift-line communities was encountered as a fragmented zone along the bay of Atalanti and in the coastal area of the Spercheios River Delta. The vegetation observed in this zone was exclusively represented by scattered stands of Cakile maritima and Salsola kali. The floristic composition of these stands allows their classifi- cation within the Cakiletea maritimae as the Salsolo kali-Cakiletum maritimae (Table 2).

\section{Embryonic shifting dunes (habitat code: 2110)}

Embryonic shifting dunes are the first stage of dune development and their vegetation colonises areas of incipient dune formation. The vegetation of this habitat type was represented by a discernible plant community composed of several psammophytes, all character and diagnostic species of the Ammophiletea. The pioneer species of the embryonic shifting dunes, Elytrigia juncea, along with Eryngium maritimum and Sporobolus virginicus, constitute a typical association of this habitat

Table 2

Salsolo kali-Cakiletum maritimae Costa et Mansanet 1981 corr. Rivas-Martinez, Costa \& Loidi 1992 (1-5)

(Euphorbion peplis, Euphorbietalia pepli, Cakiletea maritimae)

Eryngio-Sporoboletum virginici Géhu \& Uslu 1989 (6-14)

(Agropyrion juncei, Ammophiletalia, Ammophiletea)

\begin{tabular}{lllllllllllllll}
\hline Plot size $\left(\mathrm{m}^{2}\right)$ & 10 & 5 & 10 & 10 & & 20 & 20 & 15 & 18 & 20 & 20 & 18 & 15 & \\
Species N. & 7 & 5 & 6 & 5 & & 5 & 7 & 9 & 9 & 9 & 7 & 6 & 8 & \\
Relevé N. & 1 & 2 & 3 & 4 & 5 & 6 & 7 & 8 & 9 & 10 & 11 & 12 & 13 & 14
\end{tabular}

Characteristics

Cakile maritima

Salsola kali

Elytrigia juncea

Eryngium maritimum

Sporobolus virginicus

Euphorbia parallias

Lotus cytisoides

Medicago marina

Companions

Matthiola tricuspidata

Parapholis incurva

Anthemis tomentosa

Anisantha rubens

Lagurus ovatus

Halimione portulacoides

Xanthium strumarium

Polypogon monspeliensis

Limonium bellidifolium

Crithmum maritimum

$\begin{array}{lllll}2 \mathrm{a} & 2 \mathrm{a} & 1 & \cdot & \mathrm{IV} \\ \cdot & \cdot & \cdot & 2 \mathrm{~m} & \mathrm{II} \\ \cdot & \cdot & \cdot & \cdot & \\ \cdot & \cdot & \cdot & \cdot & \\ \cdot & \cdot & \cdot & \cdot & \\ . & \cdot & \cdot & \cdot & \\ 2 \mathrm{~b} & 1 & \cdot & \cdot & \mathrm{III} \\ . & \cdot & \cdot & . & \end{array}$

r

$\begin{array}{lllllll}. & \mathrm{r} & 2 \mathrm{~m} & . & . & . & \text { II } \\ . & \cdot & \cdot & . & . & . & \\ 1 & 4 & 3 & 5 & \mathrm{r} & 2 \mathrm{a} & \mathrm{V} \\ 2 \mathrm{~b} & \mathrm{r} & 4 & 2 \mathrm{~b} & 2 \mathrm{~m} & 4 & \text { IV } \\ . & . & 2 \mathrm{~b} & 2 \mathrm{a} & 3 & 4 & \text { III } \\ 2 \mathrm{~m} & 4 & \mathrm{r} & . & . & . & \text { III } \\ . & . & . & . & . & . & . \\ . & . & 3 & . & . & . & \text { I }\end{array}$

Reichardia picroides

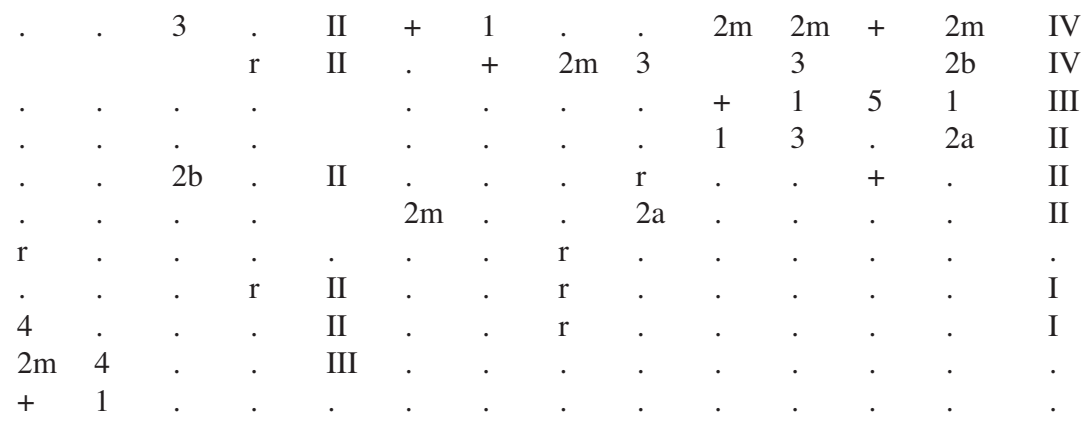

Other species: Capparis spinosa 3, Silene sedoides $\mathrm{r}$ in 1; Parietaria cretica $\mathrm{r}$ in 2; Brassica geniculata and Phragmites australis 2a, Avena barbata + in 3; Atriplex prostrata and Cynodon dactylon 1 in 4; Limonium graecum $\mathrm{r}$ in 6; Hordeum murinum subsp. leporinum 2m, Atriplex prostrata + in 7; Spergularia salina and Lolium rigidum subsp. rigidum 2m, Juncus acutus $\mathrm{r}$ in 8, Melilotus segetalis 2, Sarcocornia perennis 1 in 9; Medicago littoralis $2 \mathrm{~m}$ in 13. Localities: 1-3, 7, 9-11, 13: Atalanti wetland; 4, 6, 8, 12: Spercheios River Delta. 
type - the Eryngio-Sporoboletum virginici, which was encountered in the Spercheios River Delta and in the bay of Atalanti (Table 2). The Eryngio-Sporoboletum virginici usually grows in places that are temporarily inundated by the sea. It is the most halophytic of the dune communities and shows a greater resistance to inundation than the vegetation on other sand dunes (SÝKORA \& al., 2003).

Malcolmietalia dune grasslands (habitat code: 2230)

Matthiola tricuspidata, Anthemis tomentosa, Medicago littoralis, and Silene colorata all diag- nostic species of the class Thero-Brachypodietea (DíEZ-GARRETAS \& al., 2003), are the inhabitants of this habitat type which occurs in the Spercheios River Delta and in the coastal wetlands near the village of Oropos (Table 3). They have developed at extended patches in which were abundant and constantly present. The above-mentioned stands of the Thero-Brachypodietea belong to the Cutandietalia maritimae the Alkanno tinctoriae-Maresion nanae. These syntaxa, which have Mediterranean distribution comprise ephemeral plant communities found on coastal sands and dunes with salt spray.

The Aeluropus littoralis dominated stands observed in the wetlands of Oropos, in the Sper-

Table 3

Aeluropus littoralis comm. (1-11)

Mathiola tricuspidata-Anthemis tomentosa comm. (12-18)

(Alkano tinctoriae-Maresion nanae, Cutandietalia maritimae, Thero-Brachypodietea)

\begin{tabular}{|c|c|c|c|c|c|c|c|c|c|c|c|c|c|c|c|c|c|c|}
\hline Plot size $\left(\mathrm{m}^{2}\right)$ & 10 & 15 & 15 & 20 & 20 & 10 & 10 & 20 & 20 & 20 & & 20 & 20 & 20 & 20 & 20 & 20 & \\
\hline Species N. & 6 & 6 & 7 & 6 & 6 & 6 & 5 & 12 & 7 & 11 & & 8 & 10 & 10 & 9 & 8 & 7 & \\
\hline Relevé N. & 1 & 2 & 3 & 4 & 5 & 6 & 7 & 8 & 9 & 10 & 11 & 12 & 13 & 14 & 15 & 16 & 17 & 18 \\
\hline \multicolumn{19}{|l|}{ Characteristics } \\
\hline Aeluropus littoralis & 5 & 5 & 5 & $2 b$ & 4 & 5 & 5 & 4 & 5 & $2 b$ & $\mathrm{~V}$ & $2 \mathrm{~m}$ & 1 & . & . & . & . & II \\
\hline Anthemis tomentosa & 4 & $2 b$ & $2 \mathrm{~m}$ & 3 & 1 & 4 & 1 & & . & & IV & 3 & 3 & $2 \mathrm{~m}$ & $2 \mathrm{a}$ & + & 1 & V \\
\hline Matthiola tricuspidata & 1 & $\mathrm{r}$ & + & + & 1 & . & . & $2 \mathrm{~m}$ & . & . & III & + & $2 b$ & & $2 \mathrm{a}$ & 3 & 3 & $\mathrm{~V}$ \\
\hline Medicago littoralis & . & . & . & . & . & . & . & . & . & . & . & $2 \mathrm{~m}$ & $2 \mathrm{~m}$ & 4 & $2 b$ & $2 b$ & $2 \mathrm{~m}$ & V \\
\hline Silene colorata & $2 \mathrm{a}$ & . & . & . & . & . & . & $2 \mathrm{a}$ & . & . & I & $2 \mathrm{~m}$ & $2 \mathrm{a}$ & 1 & 3 & 4 & & V \\
\hline Lagurus ovatus & $2 b$ & . & . & . & . & $2 b$ & $2 \mathrm{~m}$ & . & . & . & II & 1 & $\mathrm{r}$ & . & 1 & . & . & III \\
\hline Plantago lagopus & . & . & . & . & . & . & . & . & . & . & . & . & $2 b$ & . & 4 & 3 & 4 & IV \\
\hline Echium arenarium & . & . & . & . & . & . & . & . & . & . & . & . & 1 & . & + & $2 \mathrm{~m}$ & + & IV \\
\hline Trifolium scabrum & . & . & . & . & . & . & . & . & . & . & . & 1 & . & 1 & . & . & . & II \\
\hline $\begin{array}{l}\text { Vulpia fasciculata } \\
\text { Companions }\end{array}$ & . & . & . & . & . & . & . & . & . & . & . & . & . & $2 b$ & . & . & . & I \\
\hline Lotus cytisoides & + & + & . & . & . & . & . & . & . & . & I & . & $2 b$ & . & . & . & . & I \\
\hline Melilotus indicus & . & . & $\mathrm{r}$ & . & . & $2 \mathrm{~m}$ & . & $2 \mathrm{~m}$ & . & . & II & . & . & . & . & . & . & . \\
\hline Polycarpon tetraphyllum & 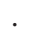 & . & . & . & . & . & . & $2 \mathrm{~m}$ & . & . & I & . & . & . & . & . & + & I \\
\hline $\begin{array}{l}\text { Hordeum murinum } \\
\text { subsp. leporinum }\end{array}$ & . & . & . & . & . & . & . & . & . & . & . & . & $r$ & . & . & + & . & I \\
\hline Avena barbata & . & . & . & . & . & . & . & . & + & . & I & . & . & . & $\mathrm{r}$ & . & . & I \\
\hline Plantago coronopus & & & & & & & & & & & & & & & & & & \\
\hline subsp. coronopus & · & · & ; & $\cdot$ & . & . & . & · & · & $2 \mathrm{~m}$ & I & · & · & $\mathrm{r}$ & . & · & · & I \\
\hline Parapholis incurva & . & . & 4 & . & . & . & . & . & . & . & I & . & . & $2 b$ & . & . & . & I \\
\hline Hordeum marinum & . & . & . & . & . & . & . & . & $2 \mathrm{~m}$ & $2 \mathrm{~m}$ & I & . & . & . & . & . & . & . \\
\hline Phalaris minor & . & . & . & . & . & . & . & - & $\mathrm{r}$ & 1 & I & . & . & . & . & . & . & . \\
\hline Rostraria cristata & . & . & . & . & + & . & . & . & $2 \mathrm{a}$ & . & I & . & . & . & . & . & . & . \\
\hline Cakile maritima & . & + & . & . & . & . & . & 1 & . & . & I & . & . & . & . & . & . & . \\
\hline
\end{tabular}

Other species: Limonium graecum + in 2; Medicago marina + in 3, Calystegia soldanella 1 in 4; Polygonum arenarium 2a in 5; Papaver rhoeas 2a, Limonium sp. $2 \mathrm{~b}$ and Linaria micrantha + in 8 ; Lolium rigidum 5, Puccinellia sp. and Parapholis filiformis 3, Phalaris paradoxa 2a in 10; Eryngium maritimum 2b in 12; Anisantha matridensis subsp. delilei + in 15. Localities: 1-3, 8, 10, 13, 15-17: Oropos wetland area; 4-7, 9, 12, 14: Spercheios River Delta; 9: Elos Sourpis. 
cheios River Delta and in the wetland Elos Sourpis were constantly associated with species of $\mathrm{Cu}$ tandietalia maritimae such as Anthemis tomentosa and Matthiola tricuspitada (Table 3). Aeluropus littoralis is widespread mostly in the coastal territories of the Mediterranean and the Black Sea Coasts and according to MucinA (1997) it is listed as a diagnostic species of the Juncetea maritimi (at least in the Mediterranean). There are several communities dominated by $A$. littoralis described from Spain and Italy (RIVASMARTÍNEZ \& al., 2001; CAZZIN \& al., 2009) as well as from the Black Sea coast of Romania (Theurillat \& MoraVeC 1998; FăGĂRAS \& al., 2003) and of Göksu Delta-Turkey (KARAÖMERLIOGLOU, 2007) included in the Juncetea maritimi. In my opinion, the floristic composition of the A. littoralis stands found in the study areas does not allow their classification within the Juncetea maritimi. With the exception of Triglochin bulbosa subsp. barrelieri and Elymus elongatus subsp. ponticus, no Juncetea maritimi species have been recorded in these stands. On the contrary, character species of the Thero-Brachypodietea, Saginetea maritimae and Stellarietea mediae were generally frequent (Table 3 ). The Aeluropetum littoralis, reported from northern Greece (BABAlonas, 1979; VASILIOU \& al., 2000), resembles several associations described from Bulgaria (TzONEV \& al., 2008), Romania (Kraush, 1965; ŞERbĂNESCU, 1965; GÉHU \& al., 1994; PoP, 2002) and Ukraine (DUBYNA \& NEUHÄUSLOVÁ, 2000). The stands of A. littoralis in the investigated areas differ floristically to a great extent from all these communities, in that they consist exclusively of character and diagnostic species belonging to the Salicocornietea fruticosae (BABALONAS, 1979; VASILIOU \& al., 2000) or the Festuco-Puccinellietea (Tzonev \& al., 2008).

Salicornia and other annuals colonising mud and sand (habitat code: Thero-Salicornietea, 1310)

The phanerogamic communities occuping the uppermost zones of the tidal mudflats are poor in species and are classified within the Thero-Salicornietea. These flood-dependent communities consist of annual succulent halophytes (Chenopodiaceae), and are confined to extreme habitats with low oxygen content in the soil. In the Mediterranean region this vegetation is mostly represented by Salicornia or Suaeda dominated phytocoenoses. These genera are taxonomically intricate encompassing many microspecies difficult to identify. According to STRID \& KIT TAN (1997) the genus Salicornia in Greece is solely represented by the species S. EUROPAEA. In our study areas the zone of tidal mudflats was thinly vegetated either by S. europaea-Spergularia salina (Elos Sourpis and Atalanti wetland) or by Spergularia salina- Suaeda splendens co-dominated stands (Spercheios River Delta) (Table 4). Spergularia salina is an annual nitro-halophilous species of coastal and continental marshes that is usually reported as a character and diagnostic species of the Juncetea maritimi (Mucina, 1997; Costa \& al., 2009) or of the Saginetea maritimae (CURCÓ, 2000). GONZĂLEZ (2009) reported from Spain a community dominated by Salicornia europaea and Spergularia marina as the Spergulario marinae-Salicornietum europeae. He classified this association within the Thero-Salicornietea, as suggested also by Rivas-MARTínEZ \& al. (2001). Likewise PEINADO \& al. (1995) reported S. marina as a therophyte that thrives in gaps within the upper salt marsh associations of the Salicornietea fruticosae, (Arthrocnemion glauci) or in the associations of the Thero-Salicornietea dominated by Suaeda (Thero-Suaedion). We suggest that our relevés with Salicornia europaea and Spergularia salina resemble the association Spergulario marinae-Salicornietum europeae.

\section{Mediterranean and thermo-Atlantic halophi- lous scrub (habitat code: Salicornietea fruti- cosae, 1420)}

In the zonation, the pioneer vegetation of the Thero-Salicornietea is usually replaced by communities of semi-woody shrubs and perennial halophytes that occur on waterlogged saline and muddy substrates and are classified as the Salicornietea fruticosae. This vegetation is not limited to the Atlantic and Mediterranean coasts, but extends also to North Africa and Middle East 


\begin{tabular}{|c|c|c|c|c|c|c|c|c|c|c|c|}
\hline \multicolumn{12}{|c|}{$\begin{array}{c}\text { Table } 4 \\
\text { Spergularia salina-Salicornia europaea comm. (1-7) } \\
\text { Spergularia salina-Suaeda spledens comm. (8-11) } \\
\text { (Thero-Salicornietalia, Thero-Salicornietea) }\end{array}$} \\
\hline Plot size $\left(\mathrm{m}^{2}\right)$ & 10 & 10 & 10 & 10 & 10 & 10 & & 5 & 5 & 8 & \\
\hline Species N. & 9 & 8 & 12 & 5 & 7 & 8 & & 6 & 6 & 7 & \\
\hline Relevé N. & 1 & 2 & 3 & 4 & 5 & 6 & 7 & 8 & 9 & 10 & 11 \\
\hline \multicolumn{12}{|l|}{ Characteristics } \\
\hline Salicornia europaea agg & $2 b$ & $2 b$ & 3 & 1 & $2 \mathrm{a}$ & 4 & $\mathrm{~V}$ & . & . & . & . \\
\hline Spergularia salina & 5 & 4 & $2 \mathrm{a}$ & 5 & 4 & $\mathrm{r}$ & $\mathrm{V}$ & 3 & $2 \mathrm{~m}$ & 5 & $\mathrm{~V}$ \\
\hline $\begin{array}{l}\text { Suaeda splendens } \\
\text { Companions }\end{array}$ & . & . & . & . & . & $2 \mathrm{a}$ & I & 3 & 5 & 1 & $\mathrm{~V}$ \\
\hline Hordeum marinum & $2 \mathrm{~m}$ & 1 & 3 & $2 \mathrm{~m}$ & . & 1 & $\mathrm{~V}$ & 1 & 1 & . & III \\
\hline Parapholis incurva & 1 & . & $2 \mathrm{~m}$ & 3 & . & . & III & . & 1 & . & II \\
\hline Plantago coronopus subsp. coronopus & . & $2 \mathrm{~b}$ & 3 & . & 3 & . & III & . & . & . & . \\
\hline Polypogon monspeliensis & $\mathrm{r}$ & . & . & . & . & 1 & II & $2 b$ & + & $2 \mathrm{~m}$ & $\mathrm{~V}$ \\
\hline Puccinelia distans subsp. distans & 3 & $2 \mathrm{a}$ & . & . & $2 \mathrm{~m}$ & . & III & $2 \mathrm{~m}$ & $2 \mathrm{~m}$ & . & III \\
\hline Tripolium pannonicum subsp. tripolium & . & . & . & . & . & $\mathrm{r}$ & $\mathrm{I}$ & . & . & + & II \\
\hline Juncus bufonius & 4 & . & 4 & . & 4 & . & III & . & . & $2 \mathrm{~b}$ & II \\
\hline Halimione portulacoides & $2 \mathrm{a}$ & . & + & $2 \mathrm{a}$ & . & . & III & . & . & . & . \\
\hline Melilotus indicus & 1 & + & . & . & . & . & II & . & . & . & . \\
\hline
\end{tabular}

Other species: Juncus hybridus 4, Carex divisa 1 in 2; Aeluropous littoralis 2a, Centaurium tenuiflorum 2b, Bupleurum tenuissimum and Polypogon maritimus 1, Medicago polymorpha + in 3; Limonium narbonense $\mathrm{r}$ in 5; Bolboschoenus maritimus 2m, Phragmites australis + in 6; Euphorbia sp.2b in 8; Puccinellia festuciformis 2m, Atriplex prostrata 1 in 10. Localities: 1, 2: Atalanti wetland; 3-5: Elos Sourpis; 6-10: Spercheios River Delta.

(KALIGARIČ \& ŠKORNIK, 2007). It is tolerant to long floods that occur during the winter, whereas in the summer it appears on dry, salt and crusty soils. In our study areas five fairly discernible communities of the halophilous scrub were encountered.

The Arthrocnemum macrostachyum stands were recorded in coastal marshy plains near the village of Oropos and in the Spercheios River Delta. Sarcocornia fruticosa and Halimione portulacoides were always present along with $A$. macrostachyum in the phytocoenoses of Oropos, and Halocnemum strobilaceum was found in the phytocoenoses of the Spercheios River Delta (Table 5). WOLFF (1968) reported from Mesolonghi a more diverse community with a similar structure as the Arthrocnemo glauci-Halocnemetum strobilacei association. Arthrocnemetum glauci and Halimiono-Arthrocnemetum glauci, reported from eastern Turkey (IsTANBULLUOGLU, 2004), have also similarities with the Arthrocnemum macrostachyum-dominated stands found in area.
Distinct patches of Sarcocornia fruticosa and Halocnemum strobilaceum, constantly associated with Parapholis incurva, were observed only in the marshy plains of Oropos (Table 5). They obviously represent a community that strongly resembles the Arthrocnemo-Halocnemetum strobilacei reported from the Göksu Delta-Turkey (Karaömerlioglu, 2007) and the Halocnemetum strobilacei reported from the Evros River Delta (BABALONAS, 1979).

In the study areas the most frequent and well represented phytocoenoses of this habitat type were Sarcocornia perennis - Halimione portulacoides stands, the majority of which were characterised by the constant and abundant presence of Puccinellia festuciformis (Table 6). WolfF(1968) and BABALONAS (1979) reported similar but more diverse communities from Mesolonghi and Evros as the Salicornietum radicantis. A community dominated by Sarcocornia perennis and Halimione portulacoides, reported from the Yumortalik Lagoon, Turkey (AlTINÖZLÜ, 2004) seems most similar to our community. 
Table 5

Arthrocnemum macrostachyum comm. (1-7)

(Arthrocnemion glauci, Salicornietalia fruticosae, Salicornietea fruticosae)

Sarcocornia fruticosa-Halocnemum strobilaceum comm. (8-13)

(Salicornion fruticosae, Salicornietalia fruticosae, Salicornietea fruticosae)

Limonium virgatum comm. (14-17) Limonium gmelinii comm. (18-20)

(Limonietalia, Salicornietea fruticosae)

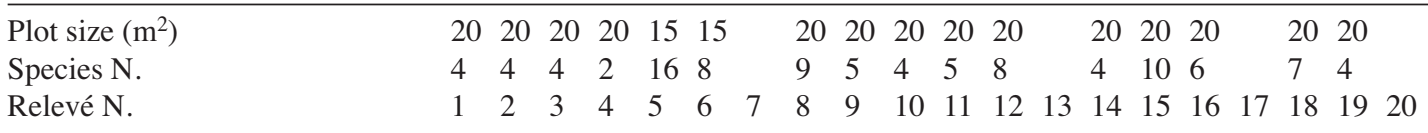

Characteristics

Arthrocnemum macrostachyum

Sarcocornia fruticosa

Halocnemum strobilaceum

Limonium virgatum

Limonium gmelinii

Companions

Halimione portulacoides

Limonium bellidifolium

Puccinelia festuciformis

Parapholis incurva

Plantago coronopus subsp.

coronopus

Melilotus indicus

Limbarda crithmoides

Sphenopus divaricatus

Spergularia salina

Sarcocornia perennis

Centaurium tenuiflorum

Triglochin bulbosa subsp.

barrelieri

Elymus elongatus

Avena sterilis subsp. ludoviciana

Lolium rigidum subsp. rigidum

Sonchus oleraceus

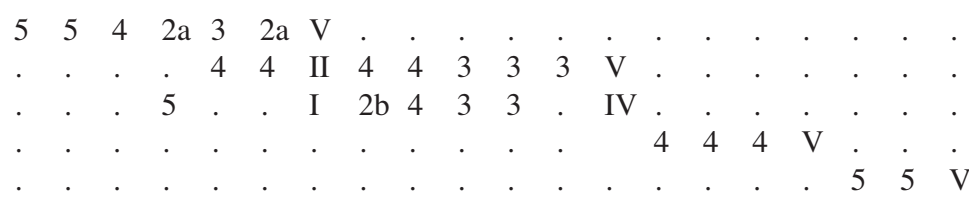

Other species: Juncus maritimus 3 in 1; Piptatherum miliaceum 2a, Medicago scutellata 2b, Phalaris minor Lolium multiflorum 2m in 5; Polypogon maritimus + in 7; Parapholis marginata 2m in 8; Limonium narbonense $2 \mathrm{~b}$ en 14. Localities: 1, 2, 5, 6, 8, 9-12: Oropos wetland area; 3, 4, 14, 18, 19: Spercheios River Delta; 15, 16: Elos Sourpis.

Two relevés with Limonium gmelinii were recorded in the Spercheios River Delta and three with $L$. virgatum, on the marshy plains of the Sourpi bay (Table 5). These probably represent communities of the Limonietalia, rich in perennial, rosette-forming Limonium spp., which in Mediterranean coastal regions occupy soils temporarily permeated (though not inundated) by saline water and are subject to extreme summer drying by formations of salt inflorescences. Similar formations are known from several coastal areas of Greece (BABALONAS, 1979).

\section{Mediterranean salt meadows (habitat code: 1410)}

Communities dominated by tall rushes, such as Juncus maritimus, J. acutus and J. subulatus, create impressive dense grasslands on subsaline soils saturated with surface or underground water and have usually been assigned to the Juncetea maritimi. These communities form a more or less continuous fringe on the transitional zone between the upper salt marsh zone and the upland vegetation, growing on sites where salt and fresh 
Table 6

Sarcocornia perennis-Halimione portulacoides comm.

(Arthrocnemion perennis, Salicornietalia fruticosae, Salicornietea fruticosae)

\begin{tabular}{|c|c|c|c|c|c|c|c|c|c|c|c|c|c|c|c|c|c|c|c|c|c|c|c|}
\hline Plot size $\left(\mathrm{m}^{2}\right)$ & 30 & 30 & 25 & 30 & 30 & 25 & 25 & 30 & 30 & 20 & 30 & 30 & 30 & 25 & 25 & 30 & 30 & 30 & 30 & 20 & 30 & 30 & \\
\hline Species N. & 3 & 6 & 4 & 3 & 2 & 5 & 4 & 4 & 7 & 5 & 4 & 4 & 5 & 6 & 3 & 4 & 5 & 3 & 2 & 6 & 5 & 5 & \\
\hline Relevé N. & 1 & 2 & 3 & 4 & 5 & 6 & 7 & 8 & 9 & 10 & 11 & 12 & 13 & 14 & 15 & 16 & 17 & 18 & 19 & 20 & 21 & 22 & 23 \\
\hline \multicolumn{24}{|l|}{ Characteristics } \\
\hline rnia perennis & $2 \mathrm{a}$ & $2 b$ & 4 & 3 & 5 & 5 & 5 & 4 & 4 & 3 & 4 & 5 & 5 & 3 & $2 b$ & $2 \mathrm{~m}$ & & 5 & 4 & 3 & 5 & 3 & $\mathrm{~V}$ \\
\hline Halimione portulacoides & . & + & 5 & $2 \mathrm{a}$ & $2 \mathrm{a}$ & 1 & 3 & 5 & $2 b$ & 4 & $2 \mathrm{a}$ & $2 b$ & $2 b$ & $2 b$ & + & 3 & . & . & . & . & . & . & IV \\
\hline Puccinelia festuciformis & . & . & . & . & . & $2 \mathrm{~m}$ & $2 \mathrm{~m}$ & $2 \mathrm{a}$ & + & $2 \mathrm{~m}$ & & $2 \mathrm{~m}$ & $2 \mathrm{a}$ & 5 & 5 & 4 & 1 & & 4 & 5 & + & & IV \\
\hline Limonium narbonense & . & . & 3 & 4 & . & . & . & + & $\cdot$ & $2 \mathrm{a}$ & + & 1 & 3 & . & ${ }^{\circ}$ & . & $\mathrm{r}$ & $\cdot$ & . & ${ }^{\circ}$ & . & . & II \\
\hline Limonium bellidifolium & . & . & . & . & . & $\mathrm{r}$ & + & . & $2 \mathrm{~m}$ & & . & . & . & . & . & . & . & . & . & . & . & 4 & I \\
\hline Limonium gmelinii & . & . & . & . & . & . & . & . & . & . & $\cdot$ & . & . & . & . & . & . & + & . & ${ }^{\circ}$ & 1 & $\mathrm{r}$ & I \\
\hline Limonium virgatum & . & . & . & . & . & . & . & . & 1 & . & . & . & . & . & . & . & . & . & . & . & . & . & I \\
\hline \multicolumn{24}{|l|}{ Companions } \\
\hline Juncus heldreichianus & . & . & $2 b$ & . & . & . & . & . & . & . & . & . & 3 & . & . & . & $2 \mathrm{a}$ & & . & . & . & . & I \\
\hline Juncus subulatus & . & . & . & . & . & . & . & . & . & . & . & . & . & 1 & . & . & . & . & . & $2 b$ & + & . & I \\
\hline Phragmites australis & $\cdot$ & . & . & . & . & . & . & . & . & . & . & . & . & . & . & . & . & . & . & + & & $\mathrm{r}$ & I \\
\hline Juncus acutus & . & . & . & . & . & . & . & . & . & $\cdot$ & $\theta^{\prime}$ & . & . & . & ${ }^{\circ}$ & . & . & ${ }^{\circ}$ & . & $\mathrm{r}$ & + & . & I \\
\hline Hordeum marinum & . & 5 & . & . & . & . & . & . & . & $2 \mathrm{~m}$ & & . & . & & . & ${ }^{\circ}$ & . & . & . & . & . & . & I \\
\hline Parapholis incurva & $2 \mathrm{a}$ & $2 \mathrm{a}$ & & . & . & . & . & . & . & . & . & . & . & & . & - & $\cdot$ & - & . & . & . & . & I \\
\hline
\end{tabular}

Other species: Triglochin bulbosa ssp. barrelieri 4 in 1; Plantago coronopus subsp. coronopus 3, Centaurium tenuiflorum + in 2; Polypogon monspeliensis in 6; Juncus maritimus 4, Limbarda crithmoides 1 in 9; Elymus elongatus + , Matthiola tricuspidata $\mathrm{r}$ in 14; Aeluropus littoralis 1 in 16; Bolboschoenus maritimus $2 \mathrm{~m}$ in 17; Tripolium pannonicum subsp. tripolium $2 \mathrm{~m}$ in 20.

Localities: 1: Oropos wetland area; 2, 3, 6-11: Elos Sourpis; 4, 5, 13, 17: Atalanti wetland; 14-16, 18-22: Spercheios River Delta.

phreatic waters mix (RIVAS-MARTÍNEZ \& al., 1980).

Stands dominated by J. maritimus or J. acutus, or both, are occasionally treated in the literature as representative segments of the Juncetum maritimo-acuti (GANIATSAS, 1936; HoRVATIĆ, 1934; Babalonas, 1979; Georgiadis \& al., 1997; FRONDONI \& IBERITE, 2002; KALIGARIČ \& ŠKORNIK, 2006), whereas in some cases they have been considered either as the Juncetum maritimi or as the Juncetum acuti (LAVRENTIADES, 1963; BABALONAS, 1979; KORAKIS \& GERASIMIDIS, 2006; KARAGIANNI \& al., 2008). In our study areas seven relevés were dominated by J. maritimus, three by $J$. maritimus along with J.acutus, whereas in five relevés J. acutus was always combined with Elymus elongatus subsp. ponticus (Table 7). We propose that all these stands should be considered as belonging to Juncetum maritimo-acuti, which was represented by its typical form and a phase with Elymus elongatus subsp. ponticus.
Two more discernible plant communities, one dominated by Juncus subulatus and one by Juncus heldreichianus, were encountered in the salt meadows of the study area (Table 8). Phytocoenoses dominated by these species are reported less frequently in the literature. KARAGIANNI \& al. (2008) mentioned a J. subulatus community from several rivers of Western Greece, and pointed out several species, such as J.acutus, Bolboschoenus maritimus, Aeluropus littoralis, Sarcocornia fruticosa, Tamarix parviflora, as coexistent in its structure. GRAdSTEIN \& SMITTENBERG (1977), who described the Juncetum subulato-maritimi noted that this vegetation was characterised by dense and floristically rather poor mats of $J$. $\mathrm{ma}$ ritimus and $J$. subulatus mixed with larger tufts of $J$. heldreichianus. Similar in structure, but without J. heldreichianus, is the Scirpo-Juncetum subulati reported from north-eastern Sardinia (BIONDI \& al., 2004) and from Lazio, Italy (FRONDONI \& IBERITE, 2002). In our case J. subulatus 
Table 7

Juncetum maritimo-acuti Horvatic 1934 (1-14)

Carex divisa-Carex distans comm. (15-18)

(Juncion maritimi, Juncetalia maritimi, Juncetea maritimi)

\begin{tabular}{lllllllllllllllllll}
\hline Plot size $\left(\mathrm{m}^{2}\right)$ & 30 & 30 & 30 & 30 & 30 & 30 & 30 & 30 & 30 & 30 & 30 & 30 & 25 & 10 & 15 & 15 & \\
Species N. & 3 & 6 & 4 & 3 & 3 & 5 & 9 & 8 & 10 & 3 & 5 & 12 & 11 & 9 & 10 & 5 \\
Relevé N. & 1 & 2 & 3 & 4 & 5 & 6 & 7 & 8 & 9 & 10 & 11 & 12 & 13 & 14 & 15 & 16 & 17 & 18 \\
\hline
\end{tabular}

Characteristics

Juncus maritimus

Juncus acutus

Elymus elongatus

Carex divisa

Carex distans

Juncus subulatus

Juncus heldreichianus

Elytrigia scirpea

Tripolium pannonicum subsp. tripolium

Triglochin bulbosa subsp. barrelieri

Companions

Sarcocornia fruticosa

Arthrocnemum macrostachyum

Limonium bellidifolium

Puccinellia festuciformis

Sarcocornia perennis

Halimione portulacoides

Phragmites australis

Daucus carota

Lotus corniculatus

Geranium dissectum

Limonium graecum

Polypogon monspeliensis

Melilotus indicus

Hordeum murinum subsp. leporinum

Marrubium peregrinum

Oenanthe silaifolia

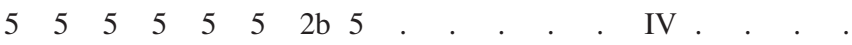

$$
\begin{aligned}
& \begin{array}{llllllll}
3 & 2 b & 3 & 2 b & 2 a & 2 b & 4 & \text { III . }
\end{array} \\
& \begin{array}{llllllllll}
4 & 4 & 5 & 4 & \text {. } & \text { II } & \cdot & \cdot & \cdot & \text {. }
\end{array} \\
& \begin{array}{cccccccccc}
\cdot & \cdot & \cdot & \cdot & . & . & 3 & 4 & 5 & \text { V } \\
. & . & . & . & \mathrm{r} & \mathrm{I} & 4 & 2 \mathrm{a} & . & \mathrm{IV}
\end{array} \\
& 2 \mathrm{~b} 3 . \text {. I . . . }
\end{aligned}
$$

Other species: Parapholis filiformis 4 ,Junc Limonium gmelinii + in $8 ;$ Bolboschoenus maritimus 1 in $9 ;$ Anagallis arvensis, Galium aparine, Picris sp. and Taraxacum sp. 1, Torilis nodosa and Ornithogalum sp. +, Vicia sativa subsp. nigra and Ophrys fusca $\mathrm{r}$ in 12; Dittrichia viscosa 3, Elytrigia juncea 2b, Bromus hordeaceus subsp. hordeaceus 2m, Limonium sinuatum +in 13; Juncus inflexus 1 in 15; Hordeum geniculatum 3, Juncus hybridus 1, Monerma cylindrica and Pulicaria dysenterica $\mathrm{r}$ in 16; Juncus articulatus 1 in 17.

Localities:1, 6: Elos Sourpis; 2-4, 7, 11-12: Oropos wetland area; 5, 8-10: Spercheios River Delta; 13, 15-17: Atalanti wetland.

formed monospecific stands, significantly resembling those of the Scirpo-Juncetum subulati from Lazio (Table 8).

Finally, three Carex divisa-Carex distans dominated relevés (Table 7) from subsaline grasslands of the Atalanti wetland should be probably assigned to the Juncetea maritimi (e. g ADAM, 1977). LAVRENTIADES (1964) reported similar but more diverse plant communities from the coasts of the western Peloponnese, stating that they resembled those described by BRAUNBLANQUET \& al. (1952) in the Mediterranean coasts of France under the Caricetum divisae. Carex divisa is typically found in damp brackish pastures near the sea (WATTS \& VILAR, 1997). 
Table 8

Juncus subulatus comm. (1-6) Juncus heldrichianus comm. (8-14)

(Juncion maritimi, Juncetalia maritimi, Juncetea maritimi)

\begin{tabular}{|c|c|c|c|c|c|c|c|c|c|c|c|c|c|c|c|}
\hline Plot size $\left(\mathrm{m}^{2}\right)$ : & 20 & 20 & 15 & 25 & 20 & 20 & & 30 & 30 & 30 & 25 & 25 & 30 & 30 & \\
\hline Species N. & 6 & 3 & 4 & 3 & 5 & 6 & & 14 & 6 & 5 & 5 & 1 & 3 & 9 & \\
\hline Relevé N. & 1 & 2 & 3 & 4 & 5 & 6 & 7 & 8 & 9 & 10 & 11 & 12 & 13 & 14 & \\
\hline \multicolumn{16}{|l|}{ Characteristics } \\
\hline Juncus subulatus & 5 & 5 & 5 & 5 & 5 & 5 & $\mathrm{~V}$ & . & . & . & . & . & . & . & . \\
\hline Juncus heldreichianus & . & . & . & . & . & . & . & 4 & 5 & 4 & 5 & 5 & 5 & 4 & $\mathrm{~V}$ \\
\hline Juncus maritimus & . & . & . & . & . & . & . & 3 & $2 \mathrm{~m}$ & 3 & . & . & . & . & III \\
\hline Elymus elongatus & . & . & . & . & . & . & . & 4 & 3 & . & . & . & . & $2 \mathrm{a}$ & III \\
\hline Juncus acutus & . & . & . & . & . & + & I & $2 \mathrm{a}$ & . & . & . & . & . & . & I \\
\hline Puccinellia distans subsp. distans & 4 & . & . & . & . & . & I & 1 & . & . & . & . & . & . & I \\
\hline Tripolium pannonicum subsp. tripolium & . & 1 & . & . & 1 & . & I & . & . & . & . & . & . & . & . \\
\hline Juncus litoralis & . & . & . & + & . & . & I & . & . & . & . & . & . & . & . \\
\hline Carex distans & . & . & . & . & . & . & . & . & . & . & . & . & . & $\mathrm{r}$ & I \\
\hline Carex divisa & . & . & . & . & . & . & . & . & . & . & 3 & . & . & . & I \\
\hline Carex extensa & . & . & . & . & . & . & . & . & $2 \mathrm{~m}$ & . & . & . & . & . & I \\
\hline Juncus gerardi subsp. gerardi & . & . & . & . & . & . & . & $2 b$ & . & . & . & . & . & . & I \\
\hline Plantago crassifolia & . & . & . & . & . & . & . & + & . & . & . & . & . & . & I \\
\hline \multicolumn{16}{|l|}{ Companions } \\
\hline Halimione portulacoides & $2 b$ & $2 b$ & . & . & . & . & II & 1 & . & . & . & . & . & . & I \\
\hline Sarcocornia perennis & $2 \mathrm{~m}$ & . & . & . & $2 \mathrm{~m}$ & . & II & . & + & . & . & . & . & . & I \\
\hline Phragmites australis & . & . & . & . & 1 & . & I & . & . & 1 & . & . & 1 & . & II \\
\hline Limonium narbonense & $2 \mathrm{a}$ & . & . & . & . & . & I & + & $\mathrm{r}$ & . & . & . & . & . & II \\
\hline Limonium bellidifolium & + & . & . & . & . & . & I & $2 \mathrm{~m}$ & . & . & . & . & + & . & II \\
\hline Puccinellia festuciformis & . & . & . & . & $2 b$ & $2 \mathrm{a}$ & II & . & . & . & . & . & . & . & . \\
\hline Bolboschoenus maritimus & . & . & . & $2 b$ & . & 3 & II & . & . & . & . & . & . & . & . \\
\hline Melica ciliata subsp. ciliata & . & . & . & . & . & . & . & . & . & . & + & . & . & + & II \\
\hline Torilis nodosa & . & . & . & . & . & . & . & 1 & & & & & & $\mathrm{r}$ & I \\
\hline
\end{tabular}

Other species: Oenanthe silaifolia 2m, Rumex conglomeratus 1 and Melilotus segetalis + in 3; Parapholis incurva 2b, Hordeum murinum subsp. leporinum + in 6; Lotus corniculatus, Cynanchum acutum and Centaurium tenuiflorum + in 8; Cyperus laevigatus subsp. distachyos 2b in 10; Elytrigia juncea 2m, Dittrichia viscosa $\mathrm{r}$ in 11; Daucus guttatus and Rostraria cristata 1, Hordeum bulbosum in 14.

Localities: 1, 8-10, 13, 14: Elos Sourpis; 2 and 5: Spercheios River Delta; 3-4, 6, 11, 12: Atalanti wetland.

\section{Reed beds (habitat code: 72A0)}

Reed beds dominated by Phragmites australis, are an important type of vegetation in Mediterranean coastal wetlands. Communities of common reed (Phragmites australis) or of reed-like tall helophytes (Typha and Scirpus), classified within the Phragmito-Magno-Caricetea, were found in all the investigated areas. These communities show a vigorous development, expanding as continuous girdles along the Asopos River mouth and in the Spercheios River Delta. In the rest of the sites studied they were represented by spot-like stands occurring through the subsaline grasslands of the Juncetea maritimi, or in muddy brackish flats amongst the perennial halophytes of Salicornietea fruticosae. This type of vegetation, which is also developed at the edges of the subsaline habitats, towards to the uplands and along ditches, mainly consisted either of Phragmites australis or of Bolboschoenus maritimus dominated stands.

Bolboschoenus maritimus stands of the Bolboschoenetum maritimi were mainly found in sites directly connected with the sea (estuaries) or in sites flooded periodically by salt water (Table 9). According to literature data (WolfF 1968; Gradstein \& SMitTEnberg 1977; Babalonas 1979; LASTRUCCI \& al., 2010) they usually achieve their optimum in the vicinity of lagoons, 
Table 9

Schoenoplectetum tabernaemontani Soó 1947 (1-3) Bolboschoenetum maritimi Eggler 1933 (5-12)

(Cirsio brachycephali-Bolboschoenion, Bolboschoenetalia, Phragmito-Magno-Caricetea)

Potamogeton pectinatus-Myriophyllum spicatum comm. (14-17)

(Potamion, Potametalia, Potametea)

\begin{tabular}{lllllllllllllllllll}
\hline Plot size $\left(\mathrm{m}^{2}\right):$ & 30 & 30 & 30 & & 30 & 30 & 30 & 30 & 30 & 30 & 30 & 30 & 30 & 30 & 30 & 30 & \\
Species number: & 4 & 5 & 10 & & 1 & 4 & 10 & 5 & 7 & 5 & 7 & 4 & & 3 & 3 & 3 & 5 & \\
Relevé N. & 1 & 2 & 3 & 4 & 5 & 6 & 7 & 8 & 9 & 10 & 11 & 12 & 13 & 14 & 15 & 16 & 17 & 18
\end{tabular}

Characteristics

Scirpus lacustris subsp. 2a $3 \quad 2 \mathrm{a} \quad \mathrm{V}$

tabernaemontani

$\begin{array}{lllllllllllll}\text { Bolboschoenus maritimus . } & \text {. } & 2 \mathrm{a} & \text { II } & 5 & 3 & 5 & 4 & 3 & 5 & 5 & 4 & \mathrm{~V}\end{array}$

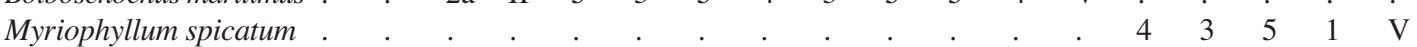

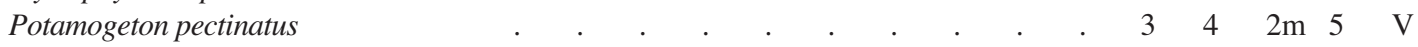

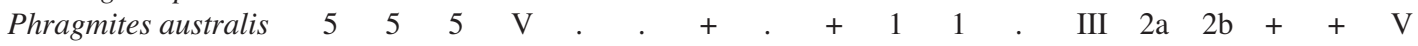

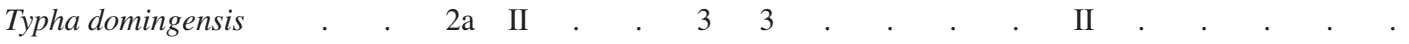

Companions

Juncus subulatus

Juncus heldreichianus $2 \mathrm{~b} \quad \cdot \quad \cdot \quad$ II

Juncus maritimus $\quad 3 \quad$. $\quad$ II

Polypogon monspeliensis $2 \mathrm{~m} \quad 2 \mathrm{~b} \quad 2 \mathrm{a} \quad \mathrm{V}$

Spergularia salina . $\quad 1$. II

Samolus valerandi $. \quad . \quad+$ II

Rumex conglomeratus

Atriplex prostrata

Oenanthe silaifolia

Trifolium fragiferum

Apium nodiflorum

Arthrocnemum

macrostachyum

Other species: Cirsium creticum 2a, Calystegia sepium $2 \mathrm{~m}$ in 3; Carex divisa 5 in 6; Hordeum murinum subsp. leporinum and Poa trivialis subsp. trivialis 2a, Alopecurus myosuroides 2b, Melica ciliata subsp. ciliata 1 in 7; Cyperus longus 3, Scirpoides holoschoenus 2b, Salix alba 1 in 8; Polypogon viridis 4, Lolium rigidum subsp. rigidum $2 \mathrm{~m}$, Rapistrum rugosum and Tamarix tetrandra + in 9; Matthiola tricuspidata + in 10; Suaeda splendens 1 in 11; Juncus acutus 2a in 12; Plantago crassifolia + in 17.

Localities: 1-3, 8, 9,12, 14-17: Elos Sourpis; 5-7, 10: Atalanti wetland; 11; Spercheios River Delta.

where salt and fresh waters mix, but they can also grow successfully in shallow waters of lakesides, ditches and rivers.

Phragmites australis stands represent the Phragmitetum communis (Table 10). The stands of this association usually thrive in fresh water habitats, but its occurrence in coastal wetlands, (BABALONAS 1979; CASSAR \& al., 2008; FĂGăRAŞ, 2008; TINNER \& al., 2009), suggest that are well adapted to such environments as well. It is well known that Phragmites australis, the essential and many times the sole species of this community, develops equally well in costal salt marshes and in fresh water wetlands lying at higher elevation. In the wetlands of the study area the typical form of this community (Table 10, rels. 1-5) was detected in slightly brackish inland sites, where soil saturation or inundation was induced mainly by fresh water. At these sites, the community included pure and very species-poor stands in which $P$. australis was the sole constituent (Elos Sourpis, Atalanti wetland and Spercheios River Delta).

On plains closer to the sea and more or less affected by salt water, two rather more halophytic variants of the community were observed: one 
Table 10

Phragmitetum communis Schmalle 1939 typicum (rels. 1-6), elymetosum elongati (rels. 7-17), juncetosum subulati (rels. 18-23)

(Phragmition communis, Phragmitetalia, Phragmito-Magno-Caricetea)

\begin{tabular}{|c|c|c|c|c|c|c|c|c|c|c|c|c|c|c|c|c|c|c|c|c|c|c|c|}
\hline Plot size $\left(\mathrm{m}^{2}\right)$ : & 30 & & 30 & 30 & 30 & & 30 & & & 30 & & 30 & 30 & 30 & 30 & 30 & & 303 & & & & 30 & \\
\hline Species number: & 3 & 6 & 2 & 1 & 1 & & 10 & 8 & 7 & 7 & 6 & 8 & 4 & 2 & 8 & 5 & & 53 & 35 & 56 & 6 & 5 & \\
\hline Relevé N. & 1 & 2 & 3 & 4 & 5 & 6 & 7 & 8 & 9 & 10 & 11 & 12 & 13 & 14 & 15 & 16 & 17 & 181 & 192 & 202 & 212 & 222 & 23 \\
\hline \multicolumn{24}{|l|}{ Characteristics } \\
\hline Phragmites australis & 5 & 5 & 5 & 5 & 5 & $\mathrm{~V}$ & 5 & 5 & 5 & 3 & 5 & 4 & 4 & 5 & 4 & 4 & $\mathrm{~V}$ & 55 & 55 & 55 & 55 & 5 & $\mathrm{~V}$ \\
\hline otus palustris s.l. & · & . & $\cdot$ & . & $\cdot$ & . & + & + & $\cdot$ & · & . & . & . & · & . & . & I & . & . & . & . & . & . \\
\hline $\begin{array}{l}\text { Bolboschoenus maritimus } \\
\text { Differentials of subass. }\end{array}$ & $\cdot$ & . & . & . & . & . & . & . & . & . & . & . & . & . & . & . & . & . & . & 1 & 1 & $1 \mathrm{I}$ & III \\
\hline elongatus & . & . & . & . & . & . & 1 & 1 & $2 \mathrm{~m}$ & & 3 & 3 & 5 & 4 & 5 & 5 & $\mathrm{~V}$ & . & . & . & . & . & . \\
\hline $\begin{array}{l}\text { Juncus subulatus } \\
\text { Companions }\end{array}$ & . & . & . & . & . & . & . & . & . & . & . & . & . & . & . & . & . & $2 b 4$ & 4 & 3. & . & +1 & IV \\
\hline tus & . & . & . & . & . & & + & . & 1 & ${ }^{\circ}$ & . & . & . & $\cdot$ & . & 1 & I & . & . & . & . & . & . \\
\hline Juncus heldreichianus & . & . & 1 & . & . & I & . & . & . & . & . & . & . & . & . & 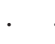 & . & . & . & . & . & . & . \\
\hline Care. & . & . & . & . & . & . & . & . & . & . & . & $2 \mathrm{a}$ & 1 & . & . & . & I & . & . & . & . & . & . \\
\hline Carex extensa & . & . & . & . & . & . & . & . & . & $2 b$ & . & $2 \mathrm{a}$ & . & . & . & $\cdot$ & I & . & . & . & . & . & . \\
\hline $\begin{array}{l}\text { Tripolium pannonicum } \\
\text { subsp. tripolium }\end{array}$ & . & . & . & . & . & . & $2 \mathrm{~m}$ & & . & . & . & . & . & . & . & . & I & $2 \mathrm{~m}$. & & . & . & . & I \\
\hline Polypogon monspeliensis & . & . & . & . & . & . & + & . & . & $2 \mathrm{~m}$ & $2 b$ & 1 & . & . & . & . & II & . & . & . & . & . & . \\
\hline iia fruticosa & $\cdot$ & . & . & . & . & . & $\cdot$ & . & $\cdot$ & . & $\cdot$ & . & + & . & 3 & $2 \mathrm{~b}$ & II & . & . & . & . & . & . \\
\hline Limonium gmelinii & . & . & . & . & . & . & + & . & + & . & . & . & . & . & . & . & I & 1 & . & . & . & . & I \\
\hline Halimione portulacoides & . & . & . & . & . & . & . & . & . & . & . & . & . & . & 1 & 1 & I & . & . & . & & . & . \\
\hline Calystegia sepium & $2 b$ & $2 \mathrm{~m}$ & 1. & . & . & II & . & $2 \mathrm{~m}$ & . & . & 1 & . & . & . & . & . & I & . & . & . & $2 \mathrm{~b}$. & . & I \\
\hline Rumex conglomeratus & . & . & . & . & . & . & 1 & . & . & . & . & . & . & . & . & . & I & 1 & 1. & . & . & $1 \mathrm{I}$ & II \\
\hline Atriplex prostrata & . & . & . & . & . & . & $\mathrm{r}$ & . & . & . & $\cdot$ & . & . & . & . & $\cdot$ & I & 1 & . & . & . & . & I \\
\hline $\begin{array}{l}\text { Beta vulgaris subsp. } \\
\text { maritima }\end{array}$ & . & 1 & . & . & . & I & . & 1 & . & . & . & . & . & . & . & . & I & . & . & . & . & . & . \\
\hline Cynanchum acutum & + & ${ }^{\circ}$ & . & . & . & I & ${ }^{\circ}$ & ${ }^{\circ}$ & $2 \mathrm{~m}$ & & $\cdot$ & ${ }^{\circ}$ & $\cdot$ & ${ }^{\circ}$ & . & & I & . & . & . & . & . & . \\
\hline Apium graveolens & & ${ }^{\circ}$ & . & . & . & . & . & . & ${ }^{\circ}$ & 1 & $2 \mathrm{a}$ & & ${ }^{\circ}$ & & $\cdot$ & & I & . & . & . & . & $\cdot$ & e \\
\hline Lotus corniculatus & $\cdot$ & . & . & . & . & . & . & . & . & + & 1 & + & . & $\cdot$ & . &. & II & . & . & $2 \mathrm{~m}$. & & . & I \\
\hline
\end{tabular}

Other species: Cichorium intybus $2 \mathrm{~m}$ and Daucus carota s.l. + in 2; Puccinellia festuciformis + in 7 ; Plantago lanceolata 1, Rumex patientia + in 8; Limbarda crithmoides 1 in 9; Puccinellia distans subsp. distans + in 10; Juncus gerardi subsp. gerardi and Carex hispida 2b in 12; Sonchus bulbosus and Limonium sp. 2a, Parapholis filiformis 2b, Centaurium tenuiflorum $\mathrm{r}$ in 15; Oenanthe silaifolia + in 19; Veronica anagalloides 2m in 20; Parentucellia viscosa 2m, Galium spurium, Vicia villosa subsp. villosa 1 in 21; Melilotus segetalis 1 in 22.

Localities: 1, 12 and 20: Elos Sourpis; 2,7-11 and 18: Spercheios River Delta; 3-5, 19 and 21-22: Atalanti wetland; 13-16: Oropos wetland area.

with Elymus elongatus subsp. ponticus (Table 10, rels. 7-16) and the other with Juncus subulatus (Table 10, rels.18-22). Each variant was characterised by the constant presence of the corresponding differential species, and we propose that both should be considered as sub-units within the Phragmitetum communis.

Schoenoplectetum tabernaemontani (Table 9) was the most restrict element of reed-bed vegeta- tion found in the area as its stands of Scirpus lacustris subsp.tabernaemontani and some locally prominent dominant species (Typha domingensis and Bolboschoenus maritimus) were encountered in Elos Sourpis solely. IRIMIA \& DANU (2010) reported similar plant community from Vaslui river basin, Romania. According to literature (FĂGĂRAŞ, 2007; LASTRUCCI \& al., 2010) communities dominated by Scirpus lacustris subsp. tabernae- 
montani thrive both on brackish and freshwater habitats.

\section{Natural eutrophic lakes with Magnopotamion or Hydrocharition-type vegetation (habitat} code: 3150 )

In the upland border of the wetland Elos Sourpis fresh water springs and shallow depressions fill up with standing water, providing ideal conditions to support a community consisting of $\mathrm{Po}$ tamogeton pectinatus and Myriophyllum spicatum (Table 9). At the height of the growing season an increase in biomass induces a spectacular development of species that cover large areas. Communities of similar structure are reported in the literature either as the Myriophyllo-Potametum (Polić \& al., 2008) or more frequently as the Po-

Table 11

Synoptic table of species constancy of studied plant communities

Salsolo kali-Cakiletum maritimae (1)

Eryngio-Sporoboletum virginici (2)

Aeluropus littoralis comm. (3), Matthiola tricuspidata-Anthemis tomentosa comm. (4)

Spergularia salina-Salicornia europaea (5), Spergularia salina-Suaeda splendens comm. (6)

Arthrocnemum macrostachyum comm. (7), Sarcocornia fruticosa-Halocnemum strobilaceum comm. (8), Limonium virgatum comm. (9), Limonium gmelinii comm. (10), Sarcocornia perennis-Halimione portulacoides comm. (11).

Quotation used (combination of the constancy class value and cover-abundance degree -amplitude- of species) are according with WeSTHOFF \& VAN DER MAAREL (1980).

\begin{tabular}{llllllllllll}
\hline N. relevés: & 4 & 8 & 10 & 6 & 6 & 3 & 6 & 5 & 3 & 2 & 22 \\
Average N. species: & 5 & 7 & 7 & 8 & 8 & 6 & 6 & 6 & 6 & 6 & 4 \\
Association N. & 1 & 2 & 3 & 4 & 5 & 6 & 7 & 8 & 9 & 10 & 11 \\
\hline
\end{tabular}

Characteristics of Salsolo kali-Cakiletum maritimae

Salsola kali

Cakile maritima

$$
\begin{array}{l|ll}
\mathrm{II}^{2 \mathrm{~m}} & & \cdot \\
\mathrm{IV}^{1-2 \mathrm{a}} & \text { II }^{\mathrm{r}-2 \mathrm{~m}} & \mathrm{I}^{+-1}
\end{array}
$$

Characteristics of Eryngio-Sporoboletum virginici.

Elytrigia juncea

Eryngium maritimum

$$
\begin{array}{l|}
\hline \mathrm{V}^{\mathrm{r}-5} \\
\mathrm{IV}^{\mathrm{r}-4}
\end{array}
$$

Aeluropus littoralis comm.

Aeluropus littoralis

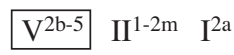

Characteristics of Matthiola

tricuspidata-Anthemis tomentosa comm.

\begin{tabular}{lllll} 
Matthiola tricuspidata & $\mathrm{II}^{3}$ & $\mathrm{IV}^{+-2 m}$ & $\mathrm{IIIr}^{-2} \mathrm{~m}$ & $\mathrm{~V}^{+-3}$ \\
Anthemis tomentosa & $\cdot$ & $\mathrm{III}^{+-5}$ & $\mathrm{IV}^{1-4}$ & $\mathrm{~V}^{+-3}$ \\
\cline { 2 - 3 }
\end{tabular}

Characteristics of Spergularia salina-Salicornia europaea comm.

Salicornia europaea agg .

Spergularia salina

\begin{tabular}{llll|} 
& $\mathrm{Ir}$ & $\cdot$ & $\mathrm{V}^{1-4}$ \\
$\mathrm{I}^{2 \mathrm{~m}}$ &. &. & $\mathrm{~V}^{\mathrm{r}-5}$ \\
\hline
\end{tabular}

Characteristics of Spergularia salina-Suaeda splendens comm.

Suaeda splendens

Arthrocnemum macrostachyum comm.

Arthrocnemum macrostachyum

Characteristics of Sarcocornia fruticosa-Halocnemum strobilaceum comm.

Sarcocornia fruticosa

Halocnemum strobilaceum

Limonium virgatum comm.

Limonium virgatum

Limonium gmelinii comm

Limonium gmelinii

Characteristics of Sarcocornia perennis-Halimione portulacoides comm.

Sarcocornia perennis

Halimione portulacoides

$\mathrm{II}^{2 \mathrm{a}-2 \mathrm{~m}}$.

$\mathrm{III}^{+-2 \mathrm{a}}$.

$\dot{V}^{1-4} \quad \mathrm{I}^{5} \quad \mathrm{~V}^{1-4} \quad \mathrm{~V}^{1-2 \mathrm{~m}} \quad \begin{gathered}\mathrm{V}^{2 \mathrm{a}-5} \\ \mathrm{I}^{\mathrm{V}-5}\end{gathered}$ 
Association N. $\begin{array}{lllllllllll}1 & 2 & 3 & 4 & 5 & 6 & 7 & 8 & 9 & 10 & 11\end{array}$

Characteristics of Phragmito-Magno-Caricetea

Phragmites australis $\mathrm{I}^{2 \mathrm{a}}$ $\mathrm{I}^{+}$ $\mathrm{I}^{\mathrm{r}}$

Bolboschoenus maritimus $\begin{array}{lllllll}\mathrm{I}^{+} & \cdot & \cdot & \cdot & \cdot & \cdot & \mathrm{I}^{\mathrm{r}} \\ \mathrm{I}^{2 \mathrm{~m}} & \cdot & \cdot & \cdot & \cdot & \cdot & \mathrm{I}^{2 \mathrm{~m}}\end{array}$

Characteristics of Salicornietea fruticosae

Limonium bellidifolium

Puccinelia festuciformis $\mathrm{II}^{4}$

Limonium narbonense

Limbarda crithmoides

Characteristics of Stellarietea mediae

Melilotus indicus

Avena barbata

Lolium rigidum

Anisantha matridensis subsp. delilei .

Hordeum murinum subsp. leporinum.

Anisantha rubens

Linaria micrantha

Phalaris minor

Rostraria cristata

Papaver rhoeas

$\begin{array}{lllllllllll}\mathrm{II}^{4} & \mathrm{I}^{\mathrm{r}} & \cdot & \cdot & \cdot & \cdot & \mathrm{III}^{+-3} & \cdot & . & . & \mathrm{I}^{\mathrm{r}-4} \\ \cdot & \cdot & \cdot & \cdot & \cdot & \mathrm{II}^{2 \mathrm{~m}} & \mathrm{I}^{3} & \cdot & \mathrm{II}^{1} & \mathrm{III}^{+} & \mathrm{IV}^{+-5} \\ \cdot & \cdot & \cdot & \cdot & \mathrm{I}^{\mathrm{r}} & \cdot & \cdot & \cdot & \mathrm{II}^{2 \mathrm{~b}} & \cdot & \mathrm{II}^{\mathrm{r}-4} \\ \cdot & \cdot & \cdot & \cdot & \cdot & \cdot & \cdot & \cdot & \mathrm{V}^{\mathrm{r}-2 \mathrm{a}} & \cdot & \mathrm{I}^{1}\end{array}$

Characteristics of Ammophiletea

Lotus cytisoides

Euphorbia parallias

Sporobolus virginicus

Medicago marina

$\begin{array}{llll}\mathrm{II}^{+} & \cdot & \mathrm{II}^{\mathrm{r}-2 \mathrm{~m}} & \cdot \\ \cdot & \mathrm{I}^{2 \mathrm{~m}} & \mathrm{I}^{+} & \mathrm{I}^{\mathrm{r}} \\ . & \cdot & \cdot & \mathrm{I}^{+} \\ . & \mathrm{I}^{2 \mathrm{~m}} & \cdot & \mathrm{I}^{\mathrm{r}-+} \\ . & \mathrm{II}^{1-2 \mathrm{a}} & \cdot & \cdot\end{array}$

$\mathrm{II}^{+-1}$

$\mathrm{II}^{\mathrm{r}-+} \quad \mathrm{II}^{2 \mathrm{a}} \quad \mathrm{II}^{+}$

Calystegia soldanella

Characteristics of Saginetea maritimae

Parapholis incurva II $^{\mathrm{r}}$

Plantago coronopus subsp. coronopus .

Polypogon monspeliensis

Centaurium tenuiflorum

Hordeum marinum

Sphenopus divaricatus

Parapholis filiformis

Parapholis marginata

Polypogon maritimus

Characteristics of Thero-Brachypodietea

\begin{tabular}{|c|c|c|c|c|}
\hline Lagurus ovatus & $\mathrm{II}^{2 \mathrm{~b}}$ & $\mathrm{II}^{\mathrm{r}-+}$ & $\mathrm{II}^{2 \mathrm{~b}-2 \mathrm{~m}}$ & $\mathrm{III}^{\mathrm{r}-1}$ \\
\hline Medicago littoralis & . & $\mathrm{I}^{2 \mathrm{~m}}$ & & $V^{2 b-4}$ \\
\hline Silene colorata & . & . & $\mathrm{I}^{2 \mathrm{a}}$ & $\mathrm{V}^{1-4}$ \\
\hline Plantago lagopus & . & . & . & $\mathrm{IV}^{2 \mathrm{~b}-4}$ \\
\hline Echium arenarium & . & . & . & $\mathrm{IV}^{+-2 \mathrm{~m}}$ \\
\hline Trifolium scabrum & . & . & . & II $^{1}$ \\
\hline Vulpia fasciculata & . & . & . & $\mathrm{I}^{2 \mathrm{~b}}$ \\
\hline
\end{tabular}

Characteristics of Crithmo-Staticetea

Crithmum maritimum

Capparis spinosa

Limonium graecum

III $^{2 \mathrm{~m}-4}$.

$\mathrm{II}^{3}$

$\begin{array}{llll}\mathrm{III}^{1-2 \mathrm{~b}} & \cdot & \mathrm{I}^{+} & \mathrm{I}^{2 \mathrm{~b}} \\ \cdot & \mathrm{III}^{\mathrm{r}-4} & \cdot & \cdot \\ \cdot & \mathrm{III}^{2 \mathrm{a}-4} & \cdot & \cdot \\ \cdot & \mathrm{I}^{3} & \mathrm{I}^{+} & \cdot \\ \cdot & \cdot & \mathrm{I}^{1} & \cdot\end{array}$

\begin{tabular}{|c|c|c|c|c|}
\hline $\mathrm{IV}^{+-3}$ & $\mathrm{I}^{4}$ & $\mathrm{I}^{2 \mathrm{~b}}$ & $\mathrm{III}^{1-3}$ & $\mathrm{II}^{1}$ \\
\hline 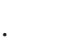 & $\mathrm{I}^{2 \mathrm{~m}}$ & $\mathrm{I}^{\mathrm{r}}$ & $\mathrm{III}^{2 \mathrm{~b}-3}$ & \\
\hline $\mathrm{I}^{\mathrm{r}}$ & . & . & $\mathrm{II}^{\mathrm{r}-1}$ & $V^{+-2 m}$ \\
\hline . & . & . & $\mathrm{I}^{2 \mathrm{~b}}$ & . \\
\hline . & $\mathrm{I}^{2 \mathrm{~m}}$ & . & $\mathrm{V}^{1-3}$ & III $^{1}$ \\
\hline . & . & . & . & . \\
\hline . & $\mathrm{I}^{3}$ & . & . & . \\
\hline . & . & . & . & . \\
\hline . & 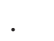 & . & $\mathrm{I}^{1}$ & . \\
\hline
\end{tabular}

$\begin{array}{llll}\mathrm{IV}^{2 \mathrm{a}-2 \mathrm{~m}} & \cdot & \cdot & \mathrm{I}^{2 \mathrm{a}} \\ \mathrm{I}^{2 \mathrm{a}} & \cdot & \cdot & \mathrm{I}^{3} \\ \mathrm{I} 1 & \cdot & \cdot & \mathrm{I}^{1} \\ \dot{\mathrm{II}^{2 b}} & \cdot & \mathrm{I}^{+} \\ \mathrm{III}^{+-2 \mathrm{a}} & \cdot & \cdot & \cdot \\ \cdot & \cdot & \cdot & \cdot \\ \cdot & \mathrm{II}^{2 \mathrm{~m}} & \cdot & \cdot \\ \cdot & \mathrm{II}^{+} & \cdot & \cdot\end{array}$

Characteristics of Juncetea maritimi

Elymus elongatus

Puccinelia distans subsp. distans

Tripolium pannonicum subsp. tripolium .

Triglochin bulbosa subsp. barrelieri .

Juncus subulatus

Juncus heldreichianus

$\begin{array}{lllllll}\cdot & \cdot & \cdot & \cdot & \mathrm{III}^{\mathrm{r}} & \mathrm{III}^{+} & \cdot \\ \mathrm{III}^{2 \mathrm{a}-3} & \mathrm{III}^{2 \mathrm{~m}} & \cdot & \cdot & \cdot & \cdot & \cdot \\ \mathrm{I}^{\mathrm{r}} & \mathrm{II}^{+} & \cdot & \cdot & \cdot & \cdot & \mathrm{I}^{2 \mathrm{~m}} \\ \cdot & \cdot & \mathrm{I}^{1} & \mathrm{I}^{2 \mathrm{a}} & \cdot & \cdot & \mathrm{I} 4 \\ \cdot & \cdot & \cdot & \cdot & \cdot & \cdot & \mathrm{I}^{+-2 \mathrm{~b}} \\ \cdot & \cdot & \cdot & \cdot & \cdot & \cdot & \mathrm{I}^{2 \mathrm{a}-3}\end{array}$




\begin{tabular}{|c|c|c|c|c|c|c|c|c|c|c|c|}
\hline Association N. & 1 & 2 & 3 & 4 & 5 & 6 & 7 & 8 & 9 & 10 & 11 \\
\hline Juncus maritimus & . & . & . & . & . & . & $\mathrm{I}^{3}$ & . & . & . & $\mathrm{I}^{4}$ \\
\hline Juncus acutus & . & $\mathrm{I}^{\mathrm{r}}$ & . & . & & . & & . & . & . & $\mathrm{I}^{\mathrm{r}-+}$ \\
\hline Carex divisa & . & . & . & . & $\mathrm{I}^{1}$ & . & . & . & . & . & . \\
\hline \multicolumn{12}{|c|}{ Characteristics of Isoeto-NanoJuncetea } \\
\hline Juncus bufonius & . & . & . & . & $\mathrm{III}^{4}$ & $\mathrm{II}^{2 \mathrm{~b}}$ & . & . & . & . & . \\
\hline Juncus hybridus & . & . & . & . & $\mathrm{I}^{4}$ & . & . & . & . & . & . \\
\hline \multicolumn{12}{|l|}{ Companion species } \\
\hline Atriplex prostrata & $\mathrm{II}^{1}$ & . & . & . & . & . & . & . & . & . & . \\
\hline Cynodon dactylon & $\mathrm{II}^{1}$ & . & . & . & . & . & . & . & . & . & . \\
\hline Melilotus segetalis & . & $\mathrm{I}^{2 \mathrm{~m}}$ & . & . & . & . & . & . & . & . & . \\
\hline Brassica geniculata & $\mathrm{II}^{2 \mathrm{a}}$ & . & . & . & . & . & . & . & . & . & . \\
\hline Limonium sp. & . & . & $\mathrm{I}^{2 \mathrm{~b}}$ & . & . & . & . & . & . & . & . \\
\hline Polygonum arenarium & . & . & $\mathrm{I}^{2 \mathrm{a}}$ & . & . & . & . & . & . & . & . \\
\hline Polycarpon tetraphyllum & . & . & $\mathrm{I}^{2 \mathrm{~m}}$ & $\mathrm{I}^{+}$ & . & . & . & . & . & . & . \\
\hline Phalaris paradoxa & . & . & $\mathrm{I}^{2 \mathrm{a}}$ & . & . & . & . & . & . & . & . \\
\hline Puccinellia sp. & . & . & $\mathrm{I}^{3}$ & . & . & . & . & . & . & . & . \\
\hline Euphorbia sp. & . & . & . & . & . & $\mathrm{II}^{2 \mathrm{~b}}$ & . & . & . & . & . \\
\hline Bupleurum tenuissimum & . & . & . & . & $\mathrm{I}^{1}$ & . & . & . & . & . & . \\
\hline Medicago polymorpha & . & . & . & . & $\mathrm{I}^{+}$ & . & . & . & . & . & . \\
\hline Medicago scutellata & . & . & . & . & . & . & $\mathrm{I}^{2 \mathrm{~b}}$ & . & . & . & . \\
\hline Avena sterilis subsp. ludoviciana & . & . & . & . & . & . & $\mathrm{I}^{3}$ & $\mathrm{I}^{+}$ & . & . & . \\
\hline Galium spurium & . & . & . & . & . & . & . & . & . & . & . \\
\hline Piptatherum miliaceum & . & . & . & . & . & . & $\mathrm{I}^{2 \mathrm{a}}$ & . & . & . & . \\
\hline Lolium multiflorum & . & . & . & . & . & . & $\mathrm{I}^{2 \mathrm{~m}}$ & . & . & . & . \\
\hline Sonchus oleraceus & . & . & . & . & . & . & $\mathrm{II}^{+-1}$ & . & . & . & . \\
\hline
\end{tabular}

Other taxa: Silene sedoides and Parietaria cretica $\mathrm{II}^{\mathrm{r}}$ and Reichardia picroides $\mathrm{III}^{+-1}$ in 1; Atriplex prostrata $\mathrm{I}^{+}$and Xanthium strumarium $\mathrm{I}^{\mathrm{r}}$ in 2; Cynodon dactylon, Cynanchum acutum and Atriplex tatarica $\mathrm{I}^{1}$, Bromus scoparius and Limonium narbonense $\mathrm{I}^{\mathrm{r}}$, Cynosurus echinatus, Anisantha diandra, Arenaria leptoclados and Hymenolobus procumbens $\mathrm{I}^{+}$in 3 .

Procedence of releves: 1: Table 2, rels. 1-5; 2: Table 2, rels. 5-14; 3: Table 3, rels.1-10; 4: Table 3, rels. 12-17; 5: Table 4, rels. 1-6; 6: Table 4, rels. 8-10; 7: Table 5, rels. 1-6; 8: Table 5, rels. 8-12; 9: Table 5, rels. 14-16; 10: Table 5, rels. $18-19$; 11: Table 6, rels. 1-22

tamo pectinati-Myriophylletum spicati (MolinA \& SARDINERO, 1998; NINOT \& al., 2000; IMERI $\& a l ., 2010)$. Both species are very phenoplastic. They usually occur in inland freshwaters, but can grow equally well in slightly brackish water where the salinity does not exceed 6\% (VAN WIJK \& al., 1988; VAN WIJCK \& al., 1994). The mechanisms by which supra-optimal salinity affects the distribution of higher plants that occur mainly in freshwater are not known, but as SCULTHORPE (1967) pointed out, they are probably varied and complex. As was demonstrated by VAN WIJK \& al. (1988) species with a wide ecological range, such as $P$. pectinatus and $M$. spicatum, develop into genetically different populations that are adapted to local habitat characteristics.

\section{Thermo-Mediterranean riparian galleries (habitat code:92D0)}

Tamarix scrub was encountered in the wetland Elos Sourpis. During our visits to the area no flowering individuals of the dominant tamarisk shrubs were found and no precise identification into species was possible. Thus, the exact syntaxonomical position of this type of vegetation is difficult to define. However the general floristic composition of stands allows their classification within the Nerio-Tamaricetea. Many taxa such as Bromus hordeaceus subsp. hordeaceus, Hordeum leporinum, Hordeum geniculatum, Torilis nodosa, Poa trivialis subsp. trivialis, Cynosurus echinatus and Halimione portulacoides were constantly associated with these phytocoenoses, 
which formed vigorous thickets in the southern part of the wetland towards its upland borders.

The halophytic vegetation found in the areas of study is highly diverse, as shown by the presence of 21 different vegetation types assigned to 12 alliances, 10 orders and 8 phytosociological classes (see syntaxonomomical scheme). The vegetation units are presented in two synoptic tables of species constancy, in which the number of relevés and the average number of species of each plant community are given (Tables 11,12 ). Species diversity of the vegetation units identified is rather diminished, as their average numbers of species did not exceed 8.6 taxa. Species poorness is a common feature of many similar vegetation units, both within Greece (LAVRENTIADES, 1964;
WolfF, 1968; BABALONAS, 1979) and in geographically more distant areas (ALCARAZ \& al., 1986; FilighedDU \& al., 2000; FRONDONI \& IBERITE, 2002; BIONDI \& al., 2004; KALIGARIČ \& ŠKORNIK, 2007; MARTIS \& SERRI, 2009).

The most diverse identified plant communities on the basis of their complexity (expressed as species diversity) were the following: Matthiola tricuspidata-Anthemis tomentosa community (average number of species 8.6), Spergularia salina-Salicornia europaea community (average number of species 8.1), Carex divisa-Carex acuta community (average number of species 8), Eryngio-Sporoboletum virginici (average number of species 7.5) and Aeluropus littoralis community (average number of species 7.2).

Table 12

Synoptic table of species constancy of studied plant communities Juncus subulatus comm. (1), Juncus heldreichianus comm. (2), Juncetum maritimo-acuti (3),

Carex divisa-Carex distans comm. (4),

Phragmitetum communis typicum (5a), elymetosum elongati (5b), juncetosum subulati (5c), Bolboschoenetum maritime (6), Schoenoplectetum tabernaemontani (7) Potamogeton pectinatus-Myriophyllum spicatum comm. (8)

Quotation used (combination of the constancy class value and cover-abundance degree -amplitude- of species) are according with WESTHOFF \& VAN DER MAAREL (1980).

\begin{tabular}{|c|c|c|c|c|c|c|c|c|c|c|}
\hline N. relevés: & 6 & 7 & 13 & 3 & 8 & 10 & 5 & 8 & 3 & 4 \\
\hline Average N. species: & 4 & 6 & 6 & 8 & 4 & 6 & 5 & 5 & 6 & 3 \\
\hline Association N. & 1 & 2 & 3 & 4 & $5 \mathrm{a}$ & $5 b$ & $5 \mathrm{c}$ & 6 & 7 & 8 \\
\hline \multicolumn{11}{|l|}{ Characteristics of Juncus subulatus comm. } \\
\hline Juncus subulatus & $\mathrm{V}^{5}$ & . & $I^{2 b-3}$ & . & . & . & $\mathrm{IV}^{+-4}$ & $\mathrm{II}^{3}$ & . & . \\
\hline \multicolumn{11}{|c|}{ Characteristics of Juncus heldreichianus comm. } \\
\hline Juncus heldreichianus & . & $\mathrm{V}^{4-5}$ & $\mathrm{I}^{\mathrm{r}}$ & . & $\mathrm{I}^{1}$ & . & . & $\mathrm{I}^{4}$ & $\mathrm{II}^{2 \mathrm{~b}}$ & . \\
\hline \multicolumn{11}{|l|}{ Juncetum maritimo-acuti } \\
\hline Juncus maritimus & . & $\mathrm{III}^{2 \mathrm{~m}-3}$ & $\mathrm{IV}^{2 \mathrm{~b}-5}$ & . & . & . & . & $\mathrm{I}^{3}$ & $\mathrm{II}^{3}$ & . \\
\hline Juncus acutus & $\mathrm{I}^{+}$ & $\mathrm{I}^{2 \mathrm{a}}$ & III $^{2 b-4}$ & . & . & $\mathrm{I}^{+-1}$ & . & $\mathrm{I}^{2 \mathrm{a}}$ & . & . \\
\hline \multicolumn{11}{|c|}{ Characteristics of Carex divisa-Carex distans comm. } \\
\hline Carex divisa & . & $\mathrm{I}^{3}$ & . & $\mathrm{V}^{3-5}$ & . & $I^{1-2 a}$ & . & $\mathrm{I}^{5}$ & . & . \\
\hline Carex distans & . & $\mathrm{I}^{\mathrm{r}}$ & $\mathrm{I}^{\mathrm{r}}$ & $I^{2 a-4}$ & . & . & . & . & . & . \\
\hline \multicolumn{11}{|l|}{ Characteristics of Phragmitetum communis } \\
\hline Phragmites australis & $\mathrm{I}^{1}$ & $\mathrm{II}^{1}$ & $\mathrm{II}^{+-2 \mathrm{~m}}$ & . & $\mathrm{V}^{5}$ & $\mathrm{~V}^{4-5}$ & $\mathrm{~V}^{5}$ & $\mathrm{III}^{+-1}$ & $\mathrm{~V}^{5}$ & . \\
\hline \multicolumn{11}{|l|}{ Bolboschoenetum maritimi } \\
\hline Bolboschoenus maritimus & $\mathrm{II}^{2 \mathrm{~b}-3}$ & . & $\mathrm{I}^{1}$ & . & & . & $\mathrm{III}^{1}$ & $\mathrm{~V}^{3-5}$ & $\mathrm{II}^{2 \mathrm{a}}$ & . \\
\hline \multicolumn{11}{|c|}{ Characteristics of Schoenoplectetum tabernaemontani } \\
\hline Scirpus lacustris subsp. tabernaemontani & & . & $\theta^{\circ}$ & . & & . & . & . & $V^{2 a-3}$ & . \\
\hline \multicolumn{11}{|c|}{ Characteristics of Potamogeton pectinatus-Myriophylleum spicatum comm. } \\
\hline Myriophyllum spicatum & . & . & . & . & . & . & . & . & . & $\mathrm{V}^{1-5}$ \\
\hline Potamogeton pectinatus & . & . & . & . & . & . & . & . & . & $\mathrm{V}^{2 \mathrm{~m}-5}$ \\
\hline \multicolumn{11}{|l|}{ Characteristics of Salicornietea fruticosae } \\
\hline Limonium bellidifolium & $\mathrm{I}^{+}$ & $\mathrm{II}^{+-2 \mathrm{~m}}$ & $\mathrm{I}^{+-2 a}$ & . & . & . & . & . & . & . \\
\hline Puccinelia festuciformis & $\mathrm{II}^{2 \mathrm{a}-2 \mathrm{~b}}$ & . & $\mathrm{I}^{\mathrm{r}-1}$ & . & . & $\mathrm{I}^{+}$ & . & . & . & . \\
\hline
\end{tabular}




\begin{tabular}{|c|c|c|c|c|c|c|c|c|c|c|}
\hline Association N. & 1 & 2 & 3 & 4 & $5 \mathrm{a}$ & $5 b$ & $5 c$ & 6 & 7 & 8 \\
\hline Limonium narbonense & $\mathrm{I} 2^{\mathrm{a}}$ & $\mathrm{I}^{\mathrm{r}-+}$ & . & . & . & . & . & . & . & . \\
\hline Limbarda crithmoides & . & . & . & . & . & $\mathrm{I}^{1}$ & . & . & . & . \\
\hline Arthrocnemum macrostachyum & . & . & $\mathrm{I} 2 \mathrm{~b}-4$ & . & . & . & . & $\mathrm{I}^{2 \mathrm{~m}}$ & . & $\mathrm{I}^{+}$ \\
\hline Sarcocornia fruticosa & . & . & $\mathrm{I}^{1-2 \mathrm{~b}}$ & . & . & $\mathrm{II}^{+-3}$ & . & . & . & . \\
\hline Limonium gmelinii & . & . & $\mathrm{I}^{+}$ & . & . & $\mathrm{I}^{+}$ & $\mathrm{I}^{1}$ & . & . & . \\
\hline Sarcocornia perennis & $\mathrm{II}^{2 \mathrm{~m}}$ & $\mathrm{I}^{+}$ & $\mathrm{II}^{+-2 \mathrm{~m}}$ & $\mathrm{II}^{+}$ & . & . & . & . & . & . \\
\hline Halimione portulacoides & $\mathrm{II}^{2 \mathrm{~b}}$ & $\mathrm{I}^{1}$ & $\mathrm{II}^{+-2 \mathrm{a}}$ & . & . & $\mathrm{I}^{1}$ & . & . & . & . \\
\hline \multicolumn{11}{|l|}{ Characteristics of Stellarietea mediae } \\
\hline Lolium rigidum & . & . & . & . & . & . & . & $\mathrm{I}^{2 \mathrm{~m}}$ & . & . \\
\hline Torilis nodosa & . & $\mathrm{I}^{\mathrm{r}-1}$ & $\mathrm{I}^{+}$ & . & . & . & . & . & . & . \\
\hline Hordeum murinum subsp. leporinum & . & . & . & $\mathrm{IV}^{3}$ & . & . & . & $\mathrm{I}^{2 \mathrm{a}}$ & . & . \\
\hline Rostraria cristata & . & $\mathrm{I}^{1}$ & . & . & . & . & . & . & . & . \\
\hline Geranium dissectum & . & . & $\mathrm{I}^{\mathrm{r}-1}$ & . & . & . & . & . & . & . \\
\hline Vicia sativa subsp. nigra & . & . & $\mathrm{I}^{\mathrm{r}-1}$ & . & . & . & . & . & . & . \\
\hline \multicolumn{11}{|l|}{ Characteristics of Juncetea maritimi } \\
\hline Elymus elongatus & . & III $^{2 \mathrm{a}-4}$ & II $^{1-5}$ & . & . & $\mathrm{V}^{1-5}$ & . & . & . & . \\
\hline Puccinelia distans subsp. distans & $\mathrm{I}^{4}$ & $\mathrm{I}^{1}$ & . & . & . & $\mathrm{I}^{+}$ & . & . & . & . \\
\hline Tripolium pannonicum subsp. tripolium & $\mathrm{I}^{1}$ & . & $\mathrm{I}^{+-1}$ & . & . & $\mathrm{I}^{2 \mathrm{~m}}$ & $\mathrm{I}^{2 \mathrm{~m}}$ & . & . & . \\
\hline Triglochin bulbosa subsp. barrelieri & . & . & $\mathrm{I}^{3}$ & $\mathrm{II}^{2 \mathrm{~m}}$ & . & . & . & . & . & . \\
\hline Juncus littoralis & $\mathrm{I}^{+}$ & . & . & . & . & . & . & . & . & . \\
\hline Elytrigia scirpea & . & . & $\mathrm{I}^{4}$ & . & . & . & . & . & . & . \\
\hline Juncus gerardi & . & $\mathrm{I}^{2 \mathrm{~b}}$ & . & . & . & $\mathrm{I}^{2 \mathrm{~b}}$ & . & . & & . \\
\hline Plantago crassifolia & . & $\mathrm{I}^{+}$ & . & . & . & . & . & . & . & $\mathrm{I}^{+}$ \\
\hline Carex extensa & . & $\mathrm{I}^{2 \mathrm{~m}}$ & . & . & . & $\mathrm{I}^{2 \mathrm{a}-2 \mathrm{~b}}$ & . & . & . & . \\
\hline Carex hispida & . & . & . & . & . & $\mathrm{I}^{2 \mathrm{~b}}$ & . & . & . & . \\
\hline \multicolumn{11}{|l|}{ Characteristics of Saginetea maritimae } \\
\hline Polypogon monspeliensis & . & . & $\mathrm{I}^{+-1}$ & $\mathrm{II}^{2 \mathrm{a}}$ & & $\mathrm{II}^{1-2 \mathrm{~m}}$ & . & $\mathrm{II}^{1-2 \mathrm{~b}}$ & $\mathrm{II}^{2 \mathrm{~m}-2 \mathrm{~b}}$ & . \\
\hline Centaurium tenuiflorum & . & $\mathrm{I}^{+}$ & $\mathrm{I}^{1}$ & . & . & Ir & . & . & . & . \\
\hline Hordeum marinum & $\mathrm{I}^{+}$ & . & . & . & . & . & . & . & . & . \\
\hline Parapholis incurva & $\mathrm{I}^{2 \mathrm{~b}}$ & . & . & . & . & . & . & . & . & . \\
\hline Parapholis filiformis & . & . & $\mathrm{I}^{4}$ & . & . & $\mathrm{I}^{2 \mathrm{a}}$ & . & . & . & . \\
\hline Spergularia salina & . & . & . & . & & . & . & $\mathrm{I}^{+}$ & $\mathrm{II}^{1}$ & . \\
\hline Parentucellia viscosa & . & . & . & . & . & . & $\mathrm{I}^{2 \mathrm{~m}}$ & . & . & . \\
\hline \multicolumn{11}{|l|}{ Characteristics of Molinio-Arrhenatheretea } \\
\hline Lotus corniculatus & . & $\mathrm{I}^{+}$ & $\mathrm{I}^{2 \mathrm{a}}$ & $\mathrm{IV}^{1-2 \mathrm{~m}}$ & . & $\mathrm{I}^{+-1}$ & $\mathrm{I}^{2 \mathrm{~m}}$ & . & . & . \\
\hline Oenanthe silaifolia & $\mathrm{I}^{2 \mathrm{~m}}$ & . & . & $\mathrm{IV}^{2 \mathrm{~m}}$ & . & . & $\mathrm{I}^{+}$ & $\mathrm{II}^{1-4}$ & . & . \\
\hline Daucus carota & . & . & $\mathrm{I}^{+}$ & $\mathrm{II}^{+}$ & $\mathrm{I}^{+}$ & . & . & . & . & . \\
\hline Bromus hordeaceus subsp. hordeaceus & . & . & $\mathrm{I}^{2 \mathrm{~m}}$ & . & . & . & . & . & . & . \\
\hline Juncus inflexus & . & . & . & $\mathrm{II}^{1}$ & . & . & . & . & . & . \\
\hline Pulicaria dysenterica & . & . & . & $\mathrm{II}^{\mathrm{r}}$ & . & . & . & . & . & . \\
\hline Hordeum geniculatum & . & . & . & $\mathrm{II}^{3}$ & . & . & . & . & . & . \\
\hline Poa trivialis subsp. trivialis & . & . & . & . & . & . & . & $\mathrm{I}^{2 \mathrm{a}}$ & . & . \\
\hline \multicolumn{11}{|l|}{ Characteristics of Isoeto-Nano-Juncetea } \\
\hline Juncus articulatus & . & . & . & $\mathrm{II}^{1}$ & . & . & . & . & . & . \\
\hline Juncus bufonius & . & . & $\mathrm{I}^{2 \mathrm{a}}$ & . & . & . & . & . & . & . \\
\hline Juncus hybridus & . & . & . & $\mathrm{II}^{1}$ & . & . & . & . & . & . \\
\hline Samolus valerandi & . & . & . & . & & . & . & . & $\mathrm{II}^{+}$ & . \\
\hline \multicolumn{11}{|c|}{ Characteristics of Phragmito-Magno-Caricetea } \\
\hline Calystegia sepium & . & . & . & . & $\mathrm{II}^{2 \mathrm{~b}-2 \mathrm{~m}}$ & $I^{1-2 m}$ & $\mathrm{I}^{2 \mathrm{~b}}$ & . & $\mathrm{II}^{2 \mathrm{~m}}$ & \\
\hline Typha domingensis & . & . & . & . & & . & . & $\mathrm{II}^{3}$ & $\mathrm{II}^{2 \mathrm{a}}$ & . \\
\hline Lotus palustris s.1. & . & . & $\mathrm{I}^{1}$ & . & . & $\mathrm{I}^{+}$ & . & . & . & . \\
\hline Companions & & & & & & & & & . & \\
\hline Rumex conglomeratus & $\mathrm{I}^{1}$ & . & $\cdot$ & . & . & $\mathrm{I}^{1}$ & $\mathrm{II}^{1}$ & $\mathrm{II}^{2 \mathrm{a}-2 \mathrm{~m}}$ & & . \\
\hline Atriplex prostrata & . & . & . & . & . & $\mathrm{I}^{\mathrm{r}}$ & $\mathrm{I}^{1}$ & $\mathrm{II}^{\mathrm{r}-2 \mathrm{~b}}$ & . & . \\
\hline
\end{tabular}




\begin{tabular}{|c|c|c|c|c|c|c|c|c|c|c|}
\hline Association $\mathrm{N}$. & 1 & 2 & 3 & 4 & $5 a$ & $5 b$ & $5 c$ & 6 & 7 & 8 \\
\hline Melilotus segetalis & $\mathrm{I}^{+}$ & . & . & . & . & . & $\mathrm{I}^{1}$ & . & . & . \\
\hline Elytrigia juncea & . & $\mathrm{I}^{2 \mathrm{~m}}$ & $\mathrm{I}^{2 \mathrm{~b}}$ & . & . & . & . & . & . & . \\
\hline Melilotus indicus & . & . & $\mathrm{I}^{1}$ & $\mathrm{II}^{2 \mathrm{~m}}$ & . & . & . & . & . & . \\
\hline Cirsium creticum & . & . & . & . & $\mathrm{I}^{2 \mathrm{~b}}$ & $\mathrm{I}^{2 \mathrm{~m}}$ & . & . & $\mathrm{II}^{2 \mathrm{a}}$ & . \\
\hline Limonium graecum & . & . & $\mathrm{II}^{+-3}$ & . & . & . & . & . & . & . \\
\hline Limonium sinuatum & . & . & $\mathrm{I}^{+-1}$ & . & . & . & . & . & . & . \\
\hline Anagallis arvensis & . & . & $\mathrm{I}^{1}$ & . & . & . & . & . & . & . \\
\hline Ornithogalum sp. & . & . & $\mathrm{I}^{+}$ & . & . & . & . & . & . & . \\
\hline Galium aparine & . & . & $\mathrm{I}^{1}$ & . & . & . & . & . & . & . \\
\hline Picris sp. & . & . & $\mathrm{I}^{1}$ & . & . & . & . & . & . & . \\
\hline Taraxacum sp. & . & . & $\mathrm{I}^{1}$ & . & . & . & . & . & . & . \\
\hline Ophrys fusca & . & . & $\mathrm{I}^{\mathrm{r}}$ & . & . & . & . & . & . & . \\
\hline Dittrichia viscosa & . & $\mathrm{I}^{\mathrm{r}}$ & $\mathrm{I}^{3}$ & . & . & . & . & . & . & . \\
\hline Rumex patientia & . & . & . & . & . & $\mathrm{I}^{+}$ & . & . & . & . \\
\hline Cyperus laevigatus subsp. distachyos & . & $\mathrm{I}^{2 \mathrm{~b}}$ & . & . & . & . & . & . & . & . \\
\hline Daucus guttatus & . & $\mathrm{I}^{1}$ & . & . & . & . & . & . & . & . \\
\hline Melica ciliata subsp. ciliata & . & $\mathrm{II}^{+}$ & . & . & . & . & . & $\mathrm{I}^{1}$ & . & . \\
\hline Hordeum bulbosum & . & $\mathrm{I}^{\mathrm{r}}$ & . & . & . & . & . & . & . & . \\
\hline Monerma cylindrica & . & . & . & $\mathrm{II}^{\mathrm{r}}$ & . & . & . & . & . & . \\
\hline Marrubium peregrinum & . & . & . & $\mathrm{r}^{-+}$ & . & . & . & . & . & . \\
\hline Cynanchum acutum & . & $\mathrm{I}^{+}$ & . & . & $\mathrm{I}^{+}$ & $\mathrm{I}^{2 \mathrm{~m}}$ & . & . & . & . \\
\hline
\end{tabular}

Other species: Cichorium intybus $\mathrm{I}^{2 \mathrm{~m}}$ in 4; Plantago lanceolata, Beta vulgaris subsp. maritima, Apium graveolens, Limonium sp. and Sonchus bulbosus $\mathrm{I}^{1}$ in 6 ; Vicia villosa $\mathrm{I}^{1}$, Galium spurium and Veronica anagalloides $\mathrm{I}^{2 \mathrm{~m}}$ in 7 ; Matthiola tricuspidata and Tamarix tetrandra $\mathrm{I}^{+}$, Suaeda splendens and Salix alba $\mathrm{I}^{1}$, Cyperus longus $\mathrm{I}^{3}$, Polypogon viridis and Rapistrum rugosum $\mathrm{I}^{4}$, Scirpoides holoschoenus and Alopecurus myosuroides $\mathrm{I}^{2 \mathrm{~b}}$ in 8 ; Apium nodiflorum and Trifolium fragiferum $\mathrm{II}^{1}$ in 9.

Procedence of releves: 1: Table 8, rels.1-6; 2: Table 8, rels. 8-14; 3: Table 7, rels. 1-13; 4; Table 7, 15-17; 5a: Table 10, rels. 1-5; 5b: Table 10, rels. 7-16; 5c: Table 10, rels. 18-22; 6: Table 9, rels. 5-12; 7: Table 9, rels. 1-3; 8: Table 9 , rels. $14-17$.

\section{ACKNOWLEDGEMENTS}

I warmly thank Prof. L. Mucina (Curtin University) for the detailed proof of manuscript and for his critical suggestions which improved the paper substantially. I also thank the anonymous reviewer for his valuable comments. Thanks are also due to Prof. V. Karakitsios (Athens University), Dr. K. Agiadi (Athens University) and Dr. D. Theocharis (Athens University) for giving us geological information of the studied ecosystems as well as to Dr. I. Bazos (Athens University) and Dr. V. Kouvelis (Athens University) for their kind assistance in the final editing of figures and tables. 


\section{SYNTAXONOMICAL SCHEME OF THE STUDIED VEGETATION UNITS}

Cakiletea maritimae Tx. et Preising ex Br.-Bl. et Tx. 1952

Euphorbietalia peplis Tx. ex. Oberd. 1949

Euphorbion peplis Tx. ex. Oberd. 1952

Salsolo kali-Cakiletum maritimae Costa et Mansanet 1981 corr. Rivas-Martinez, Costa \& Loidi 1992

AMMOPHILETEA Br.-Bl. et Tx. ex Westhoff et al. 1946

Ammophiletalia Br.-B1. 1933

Agropyrion juncei Pignatti 1953

Eryngio-Sporoboletum virginici Géhu et Uslu 1989

THERO-BRACHYPODIETEA Br.-Bl. ex A. de Bolòs y Vayreda 1950

Cutandietalia maritimae Rivas-Martinez, Díez-Garretas \& Asensi in Rivas-Martinez et al. 2002

Alkanno tinctoriae-Maresion nanae Rivas Goday ex Rivas Goday \& Rivas-Martinez 1963 corr.

Díez-Garretas, Asensi \& Rivas-Martinez 2001

Matthiola tricuspidata-Anthemis tomentosa community

Aeluropus littoralis community

Thero-SALICornietea (S. Pignatti 1953) R. Tx. in R. Tx. et Oberd. 1958

Thero-Salicornietalia Tüxen in Tüxen \& Oberdorfer ex Géhu \& Géhu-Franck 1984

Salicornion europaeo-ramosissimae Géhu \& Géhu-Franck 1984

Spergularia salina-Salicornia europaea community

Thero-Suaedion Br.-Bl. in Br.-B1., Roussine \& Nègre 1952

Suaeda splendens-Spergularia salina community

SALICORNIETEA FrUCTICOSAE Br.-Bl. et R. Tx. ex A. et O. de Bolòs 1950

Salicornietalia fruticosae Br.-Bl. 1933

Arthrocnemion perennis Rivas-Martínez in Rivas-Martinez \& Costa 1984

Sarcocornia perennis-Halimione portulacoides community

Arthrocnemion glauci Rivas-Martínez \& Costa 1984

Arthrocnemum macrostachyum community

Salicornion fruticosae Br.-B1. 1933

Sarcocornia fruticosa-Halocnemum strobilaceum community

Limonietalia Br.-Bl. \& O. de Bolòs 1958

Limonium gmelinii community

Limonium virgatum community

JUNCETEA MARITIMI R. Tx. et Oberd. 1958

Juncetalia maritimi Br.-Bl. ex Horvatić 1934

Juncion maritimi Br.-Bl. ex Horvatić 1934

Juncetum maritimo-acuti Horvatić 1934

Juncus subulatus community

Juncus heldreichianus community

Carex divisa-Carex distans community

PhraGmito-MAGNo-CARICETEA Klika in Klika et Novák 1941

Phragmitetalia W. Koch 1926

Phragmition communis W. Koch 1926

Phragmitetum communis Schmale 1939 typicum 
Phragmitetum communis Schmale 1939 elymetosum elongati

Phragmitetum communis Schmale 1939 juncetosum subulati

Bolboschoenetalia maritimi Hejný in Holub et al. 1964

Cirsio brachycephali-Bolboschoenion (Passarge 1978) Mucina in Bal.-Tul. et al. 1993

Bolboschoenetum maritimi Eggler 1933

Schoenoplectetum tabernaemontani Soó 1947

POTAMETEA Klika in Klika \& Novák 1941

Potametalia Koch 1926

Potamion (Koch 1926) Libbert 1931

Potamogeton pectinatus-Myriophyllum spicatum community

NERIO-TAMARICETEA Br.-B1. et O. de Bolós 1958

\section{REFERENCES}

Adam, P. - 1977 - On the phytosociological status of Juncus maritimus on British saltmarshes - Vegetatio 35: 81-94.

Alcaraz, A., Garre, B., Martínez, P. \& Peinado, L. -1986Phytosociological notes on the south-eastern Iberian peninsula - Collect. Bot. 16: 415-423.

Altinözlü, H. -2004- Flora of the Natural Conservation Area in Adana-Yumurtalik Lagoon (Turkey) - Turk. J. Bot. 28: 491-506.

Babalonas, D. - 1979- Phytosociological study of the vegetation of Evros Delta - Ph. D. Thesis, Aristotle University of Thessaloniki, Greece.

Babalonas, D. \& Papastergiadou, E. -1993- Phytosociological-ecological study of the Agios Mamas Lagoon (Chalkidiki, Greece) and management proposals - Laboratory of Systematic Botany and Phytogeography, School of Biology, Aristotle University and Greek Biotope/ Wetland Centre. Thessaloniki. 73 pp.

Babalonas, D., Sýkora, K. V. \& Papastergiadou, E. 1995 - Review of plant communities from Greek dunes and salt marshes, a preliminary summarizing list - Ann. Bot. (Roma) 53: 107- 117.

Bagnouls, F. \& Gaussen, H. -1953 - Saison sèche et indice xérothermique - Bull. Soc. Hist. Nat. de Toulouse 88: 193-290.

Balátová-Tuláčovă,E., Mucina, L., Ellmauer, Th. \& Wallnöfer, S. - 1993 - Phragmiti-Magnocaricetea - In: Grabherr, G. \& Mucina, L. (Eds.). Die Pflanzengesellschaften Österreichs. Volume 2. Pp. 79-130. Gustav fischer Verlag, Jena.

Barkman, J., Doing, H. \& Segal, S. -1964- Kritische Bemerkungen und Vorschläge zur quantitativen Vegetationsanalyse - Acta Bot. Neerl. 13: 394-419.

Biondi, E., Brugiapaglia, E., Farris, E., Filigheddu, R. \& Secchi, Z. - 2004- Halophilous vegetation of Olbia pond system (NE-Sardinia) - Fitosociologia 41 (1) suppl. 1: 125-141.

Braun-Blanquet, J., Negre, R. \& Roussine, N. -1952 - Les groupements végétaux de la France Méditerranéene CNRS, Paris. 297 pp.
Cassar, L.F., Conrad, E.S., Gatt, P., Lanfranco, E. \& Rolé, A. -2008 - The thermo-mediterranean biotopes of the Oued Laou basin: a landscape approach - In : Bayed, A. \& Ater, M. (Eds.). Du bassin versant vers la mer: Analyse multidisciplinaire pure une gestion durable Travaux de 1' Institut Scientifique, Rabat serie generale $5: 17-26$.

Cazzin, M., Ghirelli, L., Mion, D. \& Scarton, F. —2009Completamento della cartografia della vegetazione e degli habitat della Laguna di Venezia: Anni 2005-2007 - Lavori - Soc. Ven. Sc. Nat. 34: 81-89.

Christia, C. \& Papastergiadou, E. -2007- Spatial and temporal variations of aquatic macrophytes and water quality in six coastal lagoons of Western Greece - Belg. J. Bot. 140: 39-50.

Christia, C., Tziortzis, I., Fyttis, G., Kashta, L. \& Papastergiadou, E. - 2011 - A survey of the benthic aquatic flora in transitional water systems of Greece and Cyprus (Mediterranean Sea) - Bot. Mar. 54: 169-178.

Costa, J.C., Neto, C., Arsenio P. \& Capelo, J. -2009- Geographic variation among Iberian communities of the exotic halophyte Cotula coronopifolia - Bot. Helv. 119: 53-61.

Curcó, A. - 2000 - La vegetació del delta de l'Ebre (IV): Les comunitats nitròfiles (Classes Asplenietea trichomanis i Ruderali-Secalietea) - Acta Bot. Barcinon. 46: 143-178.

Curcó, A. - 2001 - La vegetación del delta del Ebro (V): las comunidades helofíticas e higrófilas (clases Phragmiti-Magnocaricetea y Molinio-Arrhenatheretea) - Lazaroa 22: 67-81

Cutini, M., Agostinelli, E., Acosta, T. R. A. \& Molina, J.A. -2010 - Coastal salt-marsh zonation in Tyrrhenian central Italy and its relationship with other Mediterranean wetlands - Plant Biosyst. 144: 1-11.

Dafis, S., Papastergiadou, E. \& Lazaridou, E. - 1999Technical manual of mapping of Greek habitat types (Appendix) - Greek Biotope-Wetland Centre (EKBY), Thessaloniki. 180 pp. + Supplement, 90 pp. 
Dafis, S., Papastergiadou, E., Lazaridou, E. \& Tsiafouli, M. -2001 - Technical manual of mapping of Greek habitat types - Greek Biotope-Wetland Centre (EKBY), Thessaloniki. 393 pp.

De las Heras Pérez, M.A., Muñoz Álvarez, J.M., Quijada Múñoz, J. \& Moreira Madueño, J.M. -2009- Análisis de los hábitats de interés comunitario en el entorno de Doñana - Lazaroa 30: 133-143.

Díez-Garretas, B., Asensi, A. \& Gavilán, R. -2003- Sabulicolous therophytic communities in the Mediterranean Region: a proposal of phytosociological synthesis - Phytocoenologia 33: 495-526.

Dimopoulos, P., Papastergiadou, E., Sýkora, K., Georgiadis, T., Babalonas, D. \& Dafis, S. - 1995-Collection and analysis of phytosociological data on the vegetation of Greece - Goulandris Natural History Museum and Greek Biotope-Wetland Centre (EKBY), Thessaloniki. 94 pp.

Drossos, E. - 1992 - A floristic study of Mitrikou Lake and the lagoons of Nomos Rhodopi in W Thrake (N Greece) - Willdenowia 22: 97-117.

Drossos, E., Athanasiadis, N., Theodoropoulos, K. \& Eleftheriadou, E. - 1996-Ammophilous, halophilous and hydrophilous plant communities of Delta of Thessalian pinios River (Thessalia, Hellas) - Sci. Ann. Dep. For. Nat. Env. 39: 329-365.

Dubyna, D.V. \& Neuhäuslová, Z. - 2000 - Salt meadows (Festuco-Puccinellietea) of the Birjučij Island Spit in the Azov Sea, Ukraine - Preslia 72: 31-48.

Eleftheriadou, E., Drosos, E., Athanasiadis, N. \& Theodoropoulos, K. - 1995- Contribution to the flora of the Pinios delta - Sci. Ann. Dep. For. Nat. Env. 38: 207-231.

Ellenberg, H. -1956- Grundlagen der Vegetationsgliederung. 1. Teil: Aufgaben und methoden der vegetationskunde - In: Walter, H. (Ed.). Einführung in die Phytologie - Eugen Ulmer, Stuttgart. 136 pp.

Ellenberg, H. \& Müller-Dombois, D. -1967- A key to Raunkiaer plant life forms with revised subdivisions Ber. Geob. Inst. ETH Stiftung Rübel 37: 56-73.

Emberger, L. - 1955 - Une classification biogéographique des climates - Recueil Trav. Lab. Bot. Geol. Zool. Univ. Fac. Sci. Montpellier 7: 3-43.

Emberger, L. - 1959- Orientation actuelle au service de la C. G. V. de la cartographie physiologique appliquée - Bull. Serv. Carte Phytogéogr., sér. B: 4: 119-146.

European Commision - 2003 - Interpretation manual of European Union habitats (ver. EUR25) - Brussels. $136 \mathrm{pp}$.

Făgăras, M., Bercu, R. \& Ghiduş, D. - 2003- Observations concerning ecological and floristical characteristics of Juncetum maritimi (Rubel 1930) Pign. 1953 association from the Romanian sea shore area - Contribuţii Botanice 38: 47-55.

Făgăras, M. -2007 - The plant communities from Herghelie marsh (Mangalia) Natural Reserve - An. Univ. Craiova 37: 111-122.

Făgăras, M. -2008 - Several wetlands from the Romanian Black sea Shore and their specific plant communities J. Env. Prot. Ecol. (JEPE) 9: 344-350.
Filigheddu, R., Farris, E. \& Biondi, E. - 2000 - The vegetation of S' Ena lagoon (centre-western Sardinia) - Fitosociologia 37 (1): 39-59.

Frondoni, E.R. \& Iberite, M. - 2002- The halophile vegetation of the sedimendary coast of Lazio (central Tyrrhenian district, Italy) - Plant Biosyst. 136: 49-68.

Ganiatsas, C. - 1936- Untersuchungen über die vegetation auf den Salzböden bei Saloniki - Ber. Deutsch. Bot. Ges. 54: 430-444.

García, L.V., Marañon, A., Moreno, A. \& Clemente, L. 1993- Above-ground biomass and species richness in a Mediterranean saltmarsh - J. Veg. Sci. 4: 417-424.

Garke, A. \& von Weihe, K. - 1972 - Illustrierte Flora von Deutschland undangrenzende Gebiete. Gefasskryptogamen und Blutenpflanzen - Verlag Paul Parey, Berlin. 1607 pp.

Géhu, J.M., Roman, N. \& Boullet, V. -1994- Observations nouvelles sur la végétation des côtes de Roumanie au sud du Delta du Danube - Fitosociologia 27: 73-89.

Georgiadis, Th., Economidou, E. \& Christodoulakis, D. 1990 - Flora and vegetation of strofilia coastal area (NW Peloponnesos-Greece) - Phyton (Horn, Austria) 30: $15-36$.

Georgiadis, Th., Dimopoulos, P. \& Dimitrelos, G. -1997. The flora and vegetation of the Acheron Delta (W Greecce) aiming at nature conservation - Phyton (Horn, Austria) 37: 31-60.

González, T.E. - 2009- Caracterización de los hábitats de interés comunitario (Red Natura 2000) existentes en el Principado de Asturias. I: Hábitats litorales halófilos (Dunas, Acantilados y Marismas) - Bol. Cien. Nat. R.I.D.E.A. 50: 223-280.

Gradstein, S.R. \& Smittenberg, J.H. - 1977 - The hydrophilous vegetation of western Crete - Vegetatio 34: 65-86.

Greuter, W., Burdet, H.M. \& Long, G. -1984, 1986, 1989- Med-Checklist. Volumes 1, 3, 4 - Conservatoire et Jardin Botanique, Genève.

Greuter, W., Burdet, H. M. \& Long, G. -2008- MedChecklist. Volume 2 - Conservatoire et Jardin Botanique, Genève.

Horvat, I., Glavač, V. \& Ellenberg, H. -1974 - Vegetation Südosteuropas - G. Fischer, Stuttgart. 768 pp.

Horvatić, S. - 1934 - Flora i vegetacija otoka Paga - Prir. Istraž. Jugosl. Akad. Znan. Umjet. 19: 116-372.

Imeri, A., Mullaj, A., Dodona, E. \& Kupe, L. -2010 - Coastal vegetation of the Lalzi bay (Albania) - Bot. Serbica 34: 99-105.

Irimia, I. \& Danu, M.A. - 2010 - Contributions to the paludal vegetation study from the Vaslui river basin Adv. Agric. \& Bot. Int. J. Bioflux Soc. (AAB BIOFLUX) 2: 1-7.

Istanbulluoglu, A. - 2004- Investigation of the vegetation on saline-alkaline soils and marshes of Igdir Plain in Turkey - Pakistan J. Biol. Sci. 7: 734-738.

Kaligarič, M \& Škornik, S. -2006- Halophile vegetation of the Slovenian seacoast: Thero-Salicornietea and Spartinetea maritimae - Hacquetia 5 (1): 25-36. 
Kaligarič, M. \& Škornik, S. -2007-Vegetation of tall rush saltmarshes (Juncetea maritimae) and saltmarsh scrubs (Arthrocnemetea fruticosae) on the Slovenian coast - Ann. Ser. His. Nat. 17: 47-58.

Karagiannakidou, B., Konstantinou, M., Lavrentiadou, S. $\&$ Drossos, E. - 2000 - Structure analysis of the vegetation of Strymon river delta (NE Greece) - In: Kamari, G., Psaras, G. \& Konstandinidis, Th. (Eds.). Proceedings of the 8th Scientific Congress of the Greek Botanical Society 5 - 8. 10. 2000. Pp.185-190. Patras, Greece.

Karagianni, P., Tiniakou, A. \& Georgiadis, Th. -2008 - A distribution model of habitat types along the rivers of W. Greece: A case-study - Fresen. Environ. Bull. 17: 713721.

Karaömerlioglu, D. -2007- Plant ecology of natural ecosystems in Gösku Delta (Sififke) - PhD Thesis (ined.), University of Adana, Adana (Turkey). 292 pp.

Katsikatsos, G. -2000- Geological map of Greece in scale 1: 50.000, sheet "Eretria" - I.G.M.E, Athens (Greece).

Kent, M. \& Coker, P. - 1992- Vegetation description and analysis: A practical approach - Belhaven Press, London. 363 pp.

Knapp, R. - 1958 - Einführung in die Pflanzensoziologie. 1: Arbeitsmethden der Pflanzensoziologie und Eigenschaften der Pflanzengesellschaften. 2nd Edition. Volume 1 - Eugen Ulmer, Stuttgart. 112 pp.

Korakis, G. \& Gerasimidis, A. -2006 - Coastal and halophytic habitats and their flora in Evrotas Delta (SE Peloponnisos, Greece) - J. Biol. Res. 6: 155-166.

Koumpli-Sovantzi, L. - 1991 - Coastal lagoon flora of NW Peloponnisos (Greece) - Willdenowia 21: 119-129.

Koumpli-Sovantzi, L. \& Vallianatou, I. - 1994- Floristic notes from aquatic stands of Central Greece (Sterea Ellas) - Candollea 49: 195-207.

Koumpli-Sovantzi, L. - 1995- Althenia filiformis Petit (Zannichelliaceae) in Greece - Phyton (Horn, Austria) 35: 243-245.

Koumpli-Sovantzi, L. - 2005 - Ricefield flora in the area of Acheloos river estuaries (W Greece). - In: Kamari, G., Bareka, P., Psaras, G., Konstandinidis, Th., Dimopoulos, P. \& Kyparissis, A. (Eds.). Proceedings of the 10th Scientific Congress of the Greek Botanical Society, 5 - 8. 5.2005. Pp. 319-323. Ioannina, Greece.

Krausch, H.D. -1965 - Vegetationskundliche Beobachtungen in Donaudelta - Limnologica 3: 271-313.

Lastrucci, L., Landi, M. \& Angiolini, C. -2010 - Vegetation analysis on wetlands in a Tuscan agricultural landscape (central Italy) - Biologia 65: 54-68.

Lavrentiades, G. - 1963 - On the vegetation of the Keramoti coasts - Boll. Ist. Bot. Univ. Catania, Ser 3, Vol. 4: 81-103.

Lavrentiades, G. - 1964- The ammophilous vegetation of the Western Peloponnesos coasts - Vegetatio 12: 223287.

Lavrentiades, G. - 1971 - On the vegetation of sand dunes of Greek coasts - Coll. Phytosociol. 1: 91-98.
Lavrentiades, G. - 1993 - Dry coastal ecosystems of Greece. In: van der Maarel, E. (Ed.). Ecosystems of the world 2A: Dry coastal ecosystems, Polar regions and Europe. Pp. 429 - 441. Elsevier, Dordrecht.

Maratos, G. - 1965- Geological map of Greece in scale 1: 50.000, sheet “Atalanti” - I.G.S.R, Athens (Greece).

Marinos, G., Anastopoulos, I., Maratos, G., Melidonis, N. \& Andronopoulos, B. - 1962- Geological map of Greece in scale 1: 50.000, sheet "Almyros" - I.G.S.R, Athens (Greece).

Marinos, G., Anastopoulos, I., Maratos, G., Melidonis, N. \& Andronopoulos, B. -1963- Geological map of Greece in scale 1: 50.000 , sheet "Stylis" - I.G.S.R,Athens (Greece).

Martis, G. \& Serri, G. - 2009- L'analisi fitosiciologica della vegetatione per il monitoraggio degli habitat nel Parco Naturalle Regionale Molentargius-Saline (Sardegna meridionale). Primi risultati - Inform. Bot. Ital. 41: 293-301.

Medinski, T. - 2007 - Soil chemical and physical properties and their influence on the plant species richness of arid South-West Africa - PhD Thesis, Univ. Stellenbosch, Stellenbosch.

Molina, J.A. - 1994 - Datos florísticos y fitosociológicos de la vega de Motril (Granada, España) - Lazaroa 14: 203-215.

Molina, J.A. - 1996- Sobre la vegetación de los humedales de la Península Ibérica (1. Phragmiti-Magnocaricetea) - Lazaroa 16: 27-88.

Molina, J.A. \& Sardinero, S. - 1998- Clasificación de las comunidades acuáticas del sector Celtibérico-Alcarreño (Centro de la Península Ibérica) - Acta Bot. Malacitana 23: 89-98.

Molina, J.A., Casermeiro, M.A. \& Moreno, P.S. - 2003Vegetation composition and soil salinity in a Spanish Mediterranean coastal ecosystem - Phytocoenologia 33: 475-494.

Mucina, L. - 1997 - Conspectus of classes of European vegetation - Folia Geobot. Phytotax. 32: 117-172.

Ninot, J.M., Carrera, J., Carrilo, E. \& Vigo, J. - 2000Syntaxonomic conspectus of the vegetation of Catalonia and Andorra. I: Hygrophilous herbaceous communities - Acta Bot. Barcinon. 46: 191-237.

Oberdorfer, E. - 1990 - Pflanzensoziologische Exkursionsflora - E. Ulmer, Stuttgart. 1050 pp.

Papastergiadou, E. \& Babalonas, D. - 1996- Salt marshes and sand dune ecosystems in the Northern Aegean coastal areas - In: Salman, A.H., Langeveld, M.J. \& Bonazoutas, M. (Eds.). Coastal management and habitat conservation. Pp. 65-74. EUCC, Leiden.

Parginos, D., Mavrides, A., Bornovas, I., Mettos, A., Katsikatsos, G. \& Koukis, G. -2007- Geological map of Greece in scale 1: 50.000, sheet "Halkida" - I.G.M.E, Athens (Greece).

Peinado, M., Alcaraz, F., Aguirre, J.L., Delgadillo, J. \& Álvarez, J. - 1995 - Similarity of zonation within California-Baja California and Mediterranean salt marshes - Southwest. Natur. 40: 388-404. 
Perelman, S.B., Chaneton, E.J., Batista, W.B., Burkart, S.E. \& León, R.J.C. - 2007- Habitat sress, species pool size and biotic resistance influence exotic plant richness in the Flooding Pampa grasslands - J. Ecol. 95: 1365-1377.

Perillo, G., Wolanski, E., Cahoon, D. \& Brinson, M. (Eds.) -2009- Coastal wetlands. An integrated ecosystem approach - Elsevier, Amsterdam. 941 pp.

Philippi, G. - 1992 - Klasse: Phragmitetea Tx. et Prsg. 42 - In: Oeberdorfer, E. (Ed.). Süddeutsche Pflanzengesellschaften, 3th Edition. Vol.1. Fels- und Mauergesellschaften, alpine Fluren, Wasser-, Verlandungs- und Mooorgesellschaften. Pp. 119-165. Gustav Fischer Verlag, Jena.

Pignatti, S. - 1982 - Flora d' Italia. Vols. 1-3 - Edagricole, Bologna.

Polić, D.M., Igić, R.S., Stojanović, S.J. \& Lazić, D.M. 2008 - The plant communities of classes HydrochariLemnetea Oberd. 1967 and Potametea Tx. et Prsg. 1942 of the Labudovo Okno locality (Serbia) - Proc. Nat. Sci. Matica Srpska Nov. Sad 115: 101-107.

Pop, I. - 2002 - Vegetaţia solurilor saraturoase din România - Contrib. Bot. 35: 285-328.

Raabe, U. \& Koumpli-Sovantzi, L. -2000 - Contribution to the flora of the Strophylia area (NW. Peloponnisos) - In: Kamari, G., Psaras, G. \& Konstandinidis, Th. (Eds.). Proc. 8th Sci. Congr. Greek Bot. Soc. 5: 368-371.

Raunkiaer, C. - 1934- The life forms of plants and statistical plant geography - Oxford Univ. Press, Oxford. $632 \mathrm{pp}$.

Rivas-Martínez, S. Costa, M., Castrovejo, S \& Valdés, E. - 1980 - Vegetación de Doñana (Huelva, España) Lazaroa 2: 5-190.

Rivas-Martínez, S., Fernández-González, F., Loidi, J., Lousã, M. \& Penas, A. -2001- Syntaxonomical checklist of vascular plant communities of Spain and Portugal to association level - Itinera Geobot. 14: 5-341.

Sarika, M., Dimopoulos, P. \& Yannitsaros, A. -2005Contribution to the knowledge of the wetland flora and vegetation of Amvrakikos Gulf, W Greece - Willdenowia 35: 69-85.

Sauvage, Ch. - 1963. Le quotient pluviothermique d' Emberger, son utilisation et la representation géographique de ses variations au Maroc - Ann. Phys. Globe Météo. Inst. Sci. Chérif. 20: 11-23.

Sculthorpe, C.D. - 1967 - The biology of aquatic vascular plants - Edward Arnold, London. 610 pp.

Serbănescu, I. -1965- Asociaţiile halophile din Câmpiă Româna - Com. Geol., St. Techn. Econ., Pedol., Ser. C 15: 1-149.

Strid, A. \& Kit Tan - 1997 - Flora Hellenica. Vol. 1 - Koeltz Sci. Books, Koenigstein.

Strid, A. \& Tan, K. -2002- Flora Hellenica. Vol. 2 - Koeltz Sci. Books, Koenigstein.
Sýkora, K.V., Babalonas, D. \& Papastergiadou, E. 2003 - Strandline and sand-dune vegetation of coasts of Greece and of some other Aegean countries - Phytocoenologia 33: 409-446.

Theurillat, J.P. \& Moravec, J. - 2003 - Index of new names of syntaxa published in 1994 - Folia Geobot. 33: 441-473

Tinner, W., van Leeuwen J. F. N., Colombaroli, D., Vesconi, E., van de Knaap W. O., Henne, P.D, Pasta, S., D’Angelo, S. \& Mantia, T. -2009- Holocene environmental and climatic changes at Gorgo Basso, a coastal lake in southern Sicily, Italy - Quatern. Sci. Rev. 28: 1498-1510.

Trigas, P. - 2003 - Contribution to the study of the endemism of the flora of the island of Evvia (w Aegean, Greece) - Ph D. Thesis, University of Patras, Patras (Greece). 341 pp.

Tutin, T.G., Burges, N.A., Chater, A.O., Edmonson, J.R., Heywood, V.H., Moore, D.M., Valentine, D.H., Walters, S.M. \& Webb, D.A. - 1968-1980 - Flora Europaea. Vols. 2-5 - Cambridge Univ. Press, Cambridge.

Tutin, T.G., Heywood, V.H., Burges, N.A., Moore, D.M., Valentine, D.H., Walters, S.M. \& Webb, D.A. -1993Flora Europaea. 2nd Edition. Vol. 1 - Cambridge University Press, Cambridge.

Tzonev, R., Lysenko, T., Gussev, Ch. \& Zhelev, P. -2008. The halophytic vegetation in south-east Bulgaria and along the Black Sea Coast - Hacquetia 7(2): 95-121.

van Wijk, R.J., van Goor, E.M.J. \& Verkley, J.A.C. 1988 - Ecological studies on Potamogeton pectinatus L. II. Autecological characteristics, with emphasis on salt tolerance, intraspecific variation and isoenzyme patterns - Aquat. Bot., 32: 239-260.

van Wijck, C., Grillas, P., de Groo, C.J. \& Ham, L. 1994- A comparison between the biomass production of Potamogeton pectinatus L. and Myriophyllum spicatum L. in the Camarque (southern France) in relation to salinity and sediment characteristics - Vegetatio 113: 171-180.

Vasiliou, A., Babalonas, D. \& Greuter W. -2000 - Analysis of vegetation and soil conditions of the Epanomi lagoon complex - In: Kamari, G., Psaras, G. \& Konstandinidis, Th. (Eds.). Proceedings of the 8th Scientific Congress of the Greek Botanical Society 5. Pp. 8995. Patras, Greece.

Watts, S. \& Vilar, L. - 1977- A comparative study of the vegetation at Aiquamolls de l' Emporda wetlands (N.E. Iberian Peninsula) - Sci. Gerundensis 23: 109-154.

Westhoff, V. \& van der Maarel, E. - 1980 - The BraunBlanquet approach - In: Whittaker, R. (Ed.). Ordination and classification of communities. Pp. 287-399. Dr. W. Junk, The Hague.

Wolff, W.J. - 1968 - The halophilous vegetation of the lagoons of Mesolonghi, Greece - Vegetatio 16: 95-134. 
APPENDIX 1

List of taxa found in the investigated coastal regions. Abbreviations are: Sp (Spercheios River Delta), Sr (Elos Sourpis), At (Atalanti wetland), and Or (Oropos wetlands).

\begin{tabular}{|c|c|c|c|}
\hline & Life form & Chorological type & Distibution \\
\hline \multicolumn{4}{|l|}{ Pteridophyta } \\
\hline \multicolumn{4}{|l|}{ Equisetaceae } \\
\hline Equisetum arvense $\mathrm{L}$. & G rhiz & Circumbor & $\mathrm{Sp}$ \\
\hline \multicolumn{4}{|l|}{ Angiospermae Dicotyledones } \\
\hline \multicolumn{4}{|l|}{ Apocynaceae } \\
\hline $\begin{array}{l}\text { Nerium oleander L. } \\
\text { Asclepiadaceae }\end{array}$ & $P$ caesp & S-Steno-Medit & $\mathrm{Sp}$ \\
\hline Cynanchum acutum $\mathrm{L}$. & P lian & Paleosubtrop & $\mathrm{Sp}, \mathrm{Sr}$ \\
\hline \multicolumn{4}{|l|}{ Boraginaceae } \\
\hline Echium arenarium Guss. & $\mathrm{H}$ bienn & Steno-Medit & Or \\
\hline \multicolumn{4}{|l|}{ Capparaceae } \\
\hline Capparis spinosa L. subsp. spinosa & NP & Eurasiat (Subtrop) & \\
\hline \multicolumn{4}{|l|}{ Caryophyllaceae } \\
\hline Arenaria leptoclados (Reichenb.) Guss. & T scap & Paleotemp & $\mathrm{Sp}, \mathrm{Or}$ \\
\hline Bolanthus thymifolius (Sm.) Phitos & Ch suffr & Endem & $\mathrm{Sp}$ \\
\hline Petrorhagia dubia (Rafin.) G. López \& Romo & T scap & S-Medit & Sp \\
\hline Cerastium glomeratum Thuill & T scap & Euro-Medit & Or \\
\hline Polycarpon tetraphyllum (L.) L. & T scap & Euro-Medit & Sp, Or \\
\hline Silene colorata Poiret & T scap & Steno-Medit & Sp, Or \\
\hline Silene fabaria (L.) Sm. subsp. fabaria & H scap & E-Medit & $\mathrm{Sr}$ \\
\hline Silene sedoides Poiret & T scap & Steno-Medit & At \\
\hline Spergularia salina J. Presl \& C. Presl & T scap & Subcosmop & $\mathrm{Sp}, \mathrm{Sr}, \mathrm{At}, \mathrm{Or}$ \\
\hline Stellaria media (L.) Vill. & T rept & Cosmop & Or \\
\hline \multicolumn{4}{|l|}{ Chenopodiaceae } \\
\hline Arthrocnemum macrostachyum (Moric.) K. Koch & Ch succH & Medit.- Macar & Sp, Or \\
\hline Atriplex prostrata Bouch. ex DC. & T scap & Circumbor & Sp, At \\
\hline Atriplex tatarica $\mathrm{L}$. & T scap & Centroas.-Euro-Medit & Sp \\
\hline Beta vulgaris subsp. maritima (L.) Arcang. & H scap & Euro-Medit & Sp \\
\hline Halimione portulacoides $\mathrm{L}$. & Ch frut & Circumbor & $\mathrm{Sp}, \mathrm{Sr}, \mathrm{At}, \mathrm{Or}$ \\
\hline Halocnemum strobilaceum (Pallas) M. Bieb. & Ch succ & S-Medit & Sp, Or \\
\hline Salicornia europaea L. & T scap & W-Europ. & $\mathrm{Sp}, \mathrm{Sr}, \mathrm{At}$ \\
\hline Salsola kali L. & T scap & Paleotemp & Sp \\
\hline Salsola soda $\mathrm{L}$. & T scap & Paleotemp & Or \\
\hline Sarcocornia fruticosa (L.) A. J. Scott & Ch succ & Euro-Medit & Or \\
\hline Sarcocornia perennis (Miller) A. J. Scott & Ch succ & Euro-Medit & $\mathrm{Sp}, \mathrm{Sr}, \mathrm{At}, \mathrm{Or}$ \\
\hline Suaeda splendens (Pourret) Gren. \& Gordon & T scap & Centroas.-N-Medit & Sp \\
\hline Suaeda maritima (L) Dumort. & T scap & Cosmop & $\mathrm{Sp}, \mathrm{Sr}, \mathrm{Or}$ \\
\hline \multicolumn{4}{|l|}{ Compositae } \\
\hline Anacyclus clavatus (Desf.) Pers. & T scap & Steno-Medit & Or \\
\hline Anthemis tomentosa $\mathrm{L}$. & T scap & NE-Medit & $\mathrm{Sp}, \mathrm{Sr}, \mathrm{At}, \mathrm{Or}$ \\
\hline Artemisia sp. & & & $\mathrm{Sr}$ \\
\hline Atractylis cancellata $\mathrm{L}$. & T scap & S-Medit & $\mathrm{Sp}$ \\
\hline Calendula arvensis (Vaill.) L. & T scap & Euro-Medit & Or \\
\hline Cichorium intibus $\mathrm{L}$. & H scap & Cosmop & Sp \\
\hline Cirsium creticum (Lam.) D'Urv. subsp. creticum & $\mathrm{H}$ bienn & NE-Medit & $\mathrm{Sp}, \mathrm{Sr}$ \\
\hline Cota tinctoria (L.) Gay & $\mathrm{H}$ bienn & Centro-Europ.-Pontica & $\mathrm{Sp}$ \\
\hline Crepis setosa Haller fil. & T scap & Euro-Medit.-Orient & $\mathrm{Sr}$ \\
\hline
\end{tabular}




\begin{tabular}{|c|c|c|c|}
\hline & Life form & Chorological type & Distibution \\
\hline Dittrichia viscosa (L.) Greuter & H scap & Euro-Medit & At \\
\hline Hypochoeris achyrophorus L. & T scap & Steno-Medit & Sp \\
\hline Limbarda crithmoides (L.) Dumort. & Ch suffr & SW-Europ. & $\mathrm{Sp}, \mathrm{Sr}$ \\
\hline Pulicaria dysenterica (L.) Bernh. & H scap & Euro-Medit & At \\
\hline Reichardia picroides (L.) Roth & H scap & Steno-Medit & At \\
\hline Rhagadiolus stellatus (L.) Gaertn. & T scap & Euro-Medit & $\mathrm{Sr}$ \\
\hline Sonchus bulbosus (L.) N. Kilian \& Greuter & G bulb & Steno-Medit & Or \\
\hline Sonchus oleraceus L. & T scap & Eurasiat & Or \\
\hline Tragopogon dubius Scop. & $\mathrm{H}$ bienn & S-Europ.-Caucas & $\mathrm{Sr}$ \\
\hline Trifolium pannonicum subsp. tripolium (L.) Greuter & H bienn & Eurasiat & $\mathrm{Sp}, \mathrm{Sr}$ \\
\hline $\begin{array}{l}\text { Xanthium strumarium } \mathrm{L} . \\
\text { Convolvulaceae }\end{array}$ & T scap & Cosmop & $\mathrm{Sp}$ \\
\hline Calystegia sepium (L.) R. Br. & H scand & Paleotemp & $\mathrm{Sp}, \mathrm{Sr}$ \\
\hline $\begin{array}{l}\text { Calystegia soldanella (L.) Roemer \& Schultes } \\
\text { Cruciferae }\end{array}$ & G rhiz & Cosmop & $\mathrm{Sp}$ \\
\hline $\begin{array}{l}\text { Brassica geniculata (Desf.) Snogerup \& } \\
\text { B. Snogerup }\end{array}$ & H scap & Medit.-Macar & $\mathrm{Sp}$, At \\
\hline Cakile maritima Scop. & T scap & Medit.-Atl & Sp, At, Or \\
\hline $\begin{array}{l}\text { Hymenolobus procumbens }(\mathrm{L} .) \\
\text { Nutt. subsp. procumbens }\end{array}$ & T scap & Subcosmop & Or \\
\hline Lepidium draba 1. & G rhiz & Medit.-Turan & Or \\
\hline Malcolmia flexиosa (Sm.) Sm. & T scap & SE-Europ. & At \\
\hline Matthiola tricuspidata (L.) R. Br. & T scap & Steno-Medit & Sp, At, Or \\
\hline Rapistrum rugosum (L.) All. & T scap & Euro-Medit & $\mathrm{Sp}$ \\
\hline $\begin{array}{l}\text { Sinapis alba L. subsp. alba } \\
\text { Euphorbiaceae }\end{array}$ & T scap & E-Medit & Or \\
\hline Euphorbia helioscopia L. & T scap & Cosmop & Or \\
\hline Euphorbia parallias L. & Ch frut & Euromedit.-Atl & $\mathrm{Sp}, \mathrm{At}$ \\
\hline $\begin{array}{l}\text { Euphorbia peplis L. } \\
\text { Fumariaceae }\end{array}$ & T rept & Euro-Medit & Or \\
\hline $\begin{array}{l}\text { Fumaria kraliki Jordan } \\
\text { Gentianaceae }\end{array}$ & T scap & S-Europ.-Sudsib & Or \\
\hline Centaurium spicatum (L.) Fritsch & T scap & Euro-Medit & $\mathrm{Sr}$ \\
\hline $\begin{array}{l}\text { Centaurium tenuiflorum (Hoffmanns. \& Link) } \\
\text { Fritsch subsp. tenuiflorum }\end{array}$ & T scap & Paleotemp & $\mathrm{Sp}, \mathrm{Sr}, \mathrm{Or}$ \\
\hline Geraniaceae & & & \\
\hline Erodium ciconium (L.) L'Hér. & T scap & Euro-Medit.-Pontico & Or \\
\hline Geranium molle subsp. brutium (Gasparr.) Graebner & H scap & NE-Medit & Or \\
\hline Geranium dissectum $\mathrm{L}$. & T scap & Subcosmop & Or \\
\hline $\begin{array}{l}\text { Geranium rotundifolium } \mathrm{L} . \\
\text { Haloracaceae }\end{array}$ & T scap & Paleotemp & $\mathrm{Sr}$ \\
\hline $\begin{array}{l}\text { Myriophyllum spicatum } \mathrm{L} \text {. } \\
\text { Labiatae }\end{array}$ & Hyd & Subcosmop.-Temper & $\mathrm{Sr}$ \\
\hline Lycopus europaeus L. & H scap & Paleotemp & $\mathrm{Sp}$ \\
\hline Marrubium peregrinum $\mathrm{L}$ & H scap & SE-Europ. & At \\
\hline $\begin{array}{l}\text { Satureja vulgaris subsp. arundana (Boiss.) } \\
\quad \text { Greuter \& Burdet }\end{array}$ & H scap & Circumbor & $\mathrm{Sp}$ \\
\hline $\begin{array}{l}\text { Vitex agnus-castus L. } \\
\text { Leguminosae }\end{array}$ & $P$ caesp & Steno-Medit.-Turan & Sp \\
\hline Lotus corniculatus L. & H scap & Paleotemp & $\mathrm{Sr}, \mathrm{At}$ \\
\hline Lotus cytisoides L. & Ch suffr & Steno-Medit & At, Or \\
\hline
\end{tabular}




\begin{tabular}{|c|c|c|c|}
\hline & Life form & Chorological type & Distibution \\
\hline Lotus palustris Willd. & H scap & Steno-Medit & $\mathrm{Sp}$ \\
\hline Medicago arabica (L.) Hudson & T scap & Euro-Medit & $\mathrm{Sr}$ \\
\hline Medicago littoralis Loisel & T scap & Euro-Medit & $\mathrm{Sp}$, At Or \\
\hline Medicago marina $\mathrm{L}$. & Ch rept & Euro-Medit & At \\
\hline Medicago polymorpha $\mathrm{L}$. & T scap & Euro-Medit & $\mathrm{Sr}$ \\
\hline Medicago scutellata (L.) Miller & T scap & Euro-Medit & Or \\
\hline Melilotus indicus (L.) All. & T scap & Medit.-Turan & $\mathrm{Sp}, \mathrm{Sr}, \mathrm{At}, \mathrm{Or}$ \\
\hline Melilotus segetalis (Brot.) Ser. & T scap & S-Medit & At \\
\hline Trifolium angustifolium L. & T scap & Euro-Medit & Sp \\
\hline Trifolium campestre Schreber & T scap & W-Paleotemp & $\mathrm{Sp}$ \\
\hline Trifolium fragiferum $\mathrm{L}$. & H rept & Paleotemp & $\mathrm{Sr}$ \\
\hline Trifolium ligusticum Loisel. & T scap & Steno-Medit & Or \\
\hline Trifolium scabrum L. & T rept & Euro-Medit & $\mathrm{Sp}$ \\
\hline Vicia sativa subsp. nigra (L.) Ehrh. & T scap & Medit.-Turan & Or \\
\hline Vicia villosa Roth subsp. villosa & T scap & Euro-Medit & At \\
\hline Linaceae & & & \\
\hline $\begin{array}{l}\text { Linum bienne Miller } \\
\text { Orobanchaceae }\end{array}$ & $\mathrm{H}$ bienn & Euromedit.-Subatl & Sp \\
\hline $\begin{array}{l}\text { Parentucellia viscosa (L.) Caruel } \\
\text { Papaveraceae }\end{array}$ & T scap & Medit.-Atl & At \\
\hline $\begin{array}{l}\text { Papaver rhoeas } \mathrm{L} \\
\text { Plantaginaceae }\end{array}$ & T scap & E-Medit & Or \\
\hline Linaria micrantha (Cav.) Hoffmanns \& Link & T scap & Steno-Medit & Or \\
\hline Plantago coronopus L. subsp. coronopus & H scap & Euro-Medit & $\mathrm{Sp}, \mathrm{Sr}, \mathrm{At}, \mathrm{Or}$ \\
\hline Plantago crassifolia Forsskål & $\mathrm{H}$ ros & Steno-Medit & $\mathrm{Sr}$ \\
\hline Plantago lagopus L. & T scap & Steno-Medit & Or \\
\hline Plantago lanceolata $\mathrm{L}$. & $\mathrm{H}$ ros & Eurasiat & $\mathrm{Sp}$ \\
\hline Veronica anagallis-aquatica $\mathrm{L}$. & H scap & Cosmop & $\mathrm{Sp}$ \\
\hline $\begin{array}{l}\text { Veronica anagalloides Guss. } \\
\text { Platanaceae }\end{array}$ & T scap & Euro-Medit & $\mathrm{Sr}$ \\
\hline $\begin{array}{l}\text { Platanus orientalis } \mathrm{L} . \\
\text { Plumbaginaceae }\end{array}$ & P scap & SE-Europ. & $\mathrm{Sp}$ \\
\hline Limonium bellidifolium (Gouan) Dumort & $\mathrm{H}$ ros & Medit.-Turan & $\mathrm{Sp}, \mathrm{Sr}, \mathrm{At}, \mathrm{Or}$ \\
\hline Limonium graecum (Poiret) Rech. fil. & Ch suffr & Steno-Medit.-Centrooccid & Sp, Or \\
\hline Limonium gmelinii (Willd.) O. Kuntze & $\mathrm{H}$ ros & Steno-Medit & Sp \\
\hline Limonium narbonense Miller & $\mathrm{H}$ ros & Euro-Medit & Sr, At \\
\hline Limonium sinuatum (L.) Miller & H scap & S-Medit & At \\
\hline $\begin{array}{l}\text { Limonium virgatum (Willd.) Fourr. } \\
\text { Polygonaceae }\end{array}$ & $\mathrm{H}$ ros & Euro-Medit & $\mathrm{Sr}$ \\
\hline Persicaria maculosa S.F. Gray & T scap & Subcosmop & $\mathrm{Sp}$ \\
\hline Polygonum arenarium Waldst. \& Kit. & T rept & SE-Europ.-Centroas & $\mathrm{Sp}$ \\
\hline Rumex conglomeratus Murray & H scap & Eurasiat & Sp, At \\
\hline $\begin{array}{l}\text { Rumex patientia } \mathrm{L} . \\
\text { Primulaceae }\end{array}$ & H scap & E-Europ.-Turan & $\mathrm{Sp}$ \\
\hline Anagallis arvensis $\mathrm{L}$. & T rept & Euro-Medit & Or \\
\hline $\begin{array}{l}\text { Samolus valerandi } \mathrm{L} . \\
\text { Ranunculaceae }\end{array}$ & H scap & Subcosmop & $\mathrm{Sr}$ \\
\hline Nigella damascena L. & T scap & Euro-Medit & $\mathrm{Sr}$ \\
\hline $\begin{array}{l}\text { Ranunculus muricatus } \mathrm{L} . \\
\text { Rubiaceae }\end{array}$ & T scap & Euro-Medit & Or \\
\hline Galium aparine L. & T scap & Eurasiat & Or \\
\hline
\end{tabular}




\begin{tabular}{|c|c|c|c|}
\hline & Life form & Chorological type & Distibution \\
\hline \multicolumn{3}{|l|}{ Salicaceae } & At \\
\hline Salix alba $\mathrm{L}$. & P scap & Paleotemp & $\mathrm{Sp}$ \\
\hline Salix fragilis $\mathrm{L}$. & P caesp & Eurosib & $\mathrm{Sp}$ \\
\hline \multicolumn{4}{|l|}{ Tamaricaceae } \\
\hline Tamarix parviflora DC. & $\mathrm{P}$ caesp & E-Medit & $\mathrm{Sp}$ \\
\hline Tamarix tetrandra Pallas ex M. Bieb. & $P$ caesp & Medit.-Turan & $\mathrm{Sp}$ \\
\hline Tamarix sp. & $P$ caesp & & $\mathrm{Sr}$ \\
\hline \multicolumn{4}{|l|}{ Umbelliferae } \\
\hline Apium graveolens $\mathrm{L}$. & H scap & Paleotemp & $\mathrm{Sr}$ \\
\hline Apium nodiflorum (L.) Lag. & H scap & Euro-Medit & $\mathrm{Sr}$ \\
\hline Bupleurum tenuissimum $\mathrm{L}$. & T scap & Euro-Medit & $\mathrm{Sr}$ \\
\hline Crithmum maritimum L. & Ch suffr & Euro-Medit & $\mathrm{Sp}, \mathrm{At}$ \\
\hline Daucus carota L. & H bienn & Paleotemp & Sp, At \\
\hline Daucus guttatus Sibth. \& Sm. & T scap & E-Medit & $\mathrm{Sp}, \mathrm{Sr}$ \\
\hline Eryngium maritimum $\mathrm{L}$. & G rhiz & Medit.-Atl & Sp, At \\
\hline Malabaila aurea (Sibth. \& Sm.) Boiss. & H scap & E-Steno-Medit & $\mathrm{Sp}$ \\
\hline Oenanthe silaifolia M. Bieb. & H scap & Medit.-Atl & At \\
\hline Smyrnium rotundifolium Miller & H bienn & S-Medit & At \\
\hline & \multicolumn{2}{|c|}{ Urticaceae } & $\mathrm{Sr}, \mathrm{At}, \mathrm{Or}$ \\
\hline Parietaria cretica $\mathrm{L}$. & T rept & Steno-Medit.-Orient & At \\
\hline \multicolumn{4}{|l|}{ Angiospermae - Monocotyledones } \\
\hline \multicolumn{4}{|l|}{ Cyperaceae } \\
\hline Bolboschoenus maritimus (L.) Palla & Hyd & Euro-Medit & $\mathrm{Sp}, \mathrm{Sr}, \mathrm{At}$ \\
\hline Carex distans L. & H caesp & Euro-Medit & $\mathrm{Sp}, \mathrm{At}$ \\
\hline Carex divisa Hudson & G rhiz & Euro-Medit & $\mathrm{Sr}, \mathrm{At}, \mathrm{Or}$ \\
\hline Carex extensa Good. & H caesp & Medit.-Atl & $\mathrm{Sp}, \mathrm{Sr}$ \\
\hline Carex hispida Willd. & G rhiz & Steno-Medit & $\mathrm{Sr}, \mathrm{At}, \mathrm{Or}$ \\
\hline Carex pendula Hudson & H caesp & Eurasiat & $\mathrm{Sp}$ \\
\hline Carex spicata Hudson & H caesp & Eurasiat & $\mathrm{Sp}$ \\
\hline Cyperus glaber $\mathrm{L}$. & T scap & Paleotemp & $\mathrm{Sp}$ \\
\hline $\begin{array}{l}\text { Cyperus laevigatus subsp. distachyos (All.) } \\
\text { Maire \& Weiller }\end{array}$ & G rhiz & Subcosmop & $\mathrm{Sr}$ \\
\hline Cyperus longus $\mathrm{L}$. & G rhiz & Paleotemp & $\mathrm{Sp}$ \\
\hline Scirpus cernuus Vahl & T scap & Subcosmop & Or \\
\hline Scirpoides holoschoenus (L.) Soják & G rhiz & Euro-Medit & $\mathrm{Sp}$ \\
\hline $\begin{array}{l}\text { Scirpus lacustris subsp. tabernaemontani } \\
\quad \text { (C.C. Gmelin) Syme }\end{array}$ & Hyd & Eurosib & $\mathrm{Sr}$ \\
\hline \multicolumn{4}{|l|}{ Gramineae } \\
\hline Aegilops triuncialis $\mathrm{L}$. & T scap & Euro-Medit & $\mathrm{Sp}$ \\
\hline Aeluropus littoralis (Gouan) Parl. & G rhiz & N-Medit.-Turan & $\mathrm{Sp}, \mathrm{Sr}, \mathrm{At}, \mathrm{Or}$ \\
\hline Alopecuros myosuroides Hudson & T scap & Paleotemp & At \\
\hline Anisantha diandra (Roth) Tutin ex Tzvelev & T scap & Euro-Medit & $\mathrm{Sp}$, Or \\
\hline $\begin{array}{l}\text { Anisantha madritensis subsp. delilei (Boiss.) } \\
\text { Bracchi, Banfi \& Galasso }\end{array}$ & T scap & Euro-Medit & $\mathrm{Sr}, \mathrm{Or}$ \\
\hline Anisantha rubens (L.) Nevski & T scap & S-Medit.-Turan & At \\
\hline Avena barbata Pott ex Link subsp. barbata & T scap & Euro-Medit.-Turan & $\mathrm{Sp}, \mathrm{Sr}, \mathrm{At}, \mathrm{Or}$ \\
\hline $\begin{array}{l}\text { Avena sterilis subsp. ludoviciana (Durieu) } \\
\text { Gillet \& MaMagne }\end{array}$ & T scap & Euro-Medit & Or \\
\hline
\end{tabular}




\begin{tabular}{|c|c|c|c|}
\hline & Life form & Chorological type & Distibution \\
\hline $\begin{array}{l}\text { Brachypodium sylvaticum (Hudson) } \\
\text { P. Beauv. subsp. sylvaticum }\end{array}$ & H caesp & Paleotemp & $\mathrm{Sp}$ \\
\hline Bromus alopecuros Poiret subsp. alopecuros & T scap & Steno-Medit & $\mathrm{Sr}$ \\
\hline Bromus hordeaceus L. subsp. hordeaceus & T scap & Subcosmop & $\mathrm{Sr}, \mathrm{At}$ \\
\hline Bromus intermedius Guss. & T scap & Euro-Medit & At \\
\hline Bromus lanceolatus Roth & T scap & Paleotemp & Or \\
\hline Bromus scoparius L. & T scap & Steno-Medit & $\mathrm{Sr}$ \\
\hline Catapodium rigidum (L.) C.E. Hubb. & T scap & Euro-Medit & Sp \\
\hline Cynodon dactylon (L.) Pers. & G rhiz & Termo-Cosmop & $\mathrm{Sp}, \mathrm{Sr}, \mathrm{Or}$ \\
\hline Cynosurus echinatus L. & T scap & Euro-Medit & $\mathrm{Sp}, \mathrm{Sr}, \mathrm{Or}$ \\
\hline Dactylis glomerata L. & H caesp & Paleotemp & $\mathrm{Sp}, \mathrm{Sr}$ \\
\hline $\begin{array}{l}\text { Elymus elongatus (Host) Runemark } \\
\text { subsp. elongatus }\end{array}$ & $H$ caesp & Euro-Medit & $\mathrm{Sp}$ \\
\hline $\begin{array}{l}\text { Elymus elongatus subsp. ponticus } \\
\text { (Podp.) Melderis }\end{array}$ & H caesp & Euro-Medit & $\mathrm{Sp}, \mathrm{Sr}, \mathrm{Or}$ \\
\hline Elymus repens (L.) Gould subsp. repens & G rhiz & Circumbor & $\mathrm{Sp}$ \\
\hline Elytrigia juncea (L.) Nevski & G rhiz & Euro-Medit & $\mathrm{Sp}, \mathrm{At}$ \\
\hline Elytrigia scirpea (C. Presl) Holub & H caesp & E-Medit & Sr, At, Or \\
\hline Hordeum bulbosum L. & H caesp & Paleosubtrop & $\mathrm{Sp}$ \\
\hline Hordeum geniculatum All. & T scap & Steno-Medit & $\mathrm{Sr}, \mathrm{At}$ \\
\hline Hordeum marinum Hudson & T scap & Euro-Medit.-Occid & $\mathrm{Sp}, \mathrm{Sr}, \mathrm{At}, \mathrm{Or}$ \\
\hline $\begin{array}{l}\text { Hordeum murinum subsp. leporinum } \\
\text { (Link) Arcang. }\end{array}$ & T scap & Euro-Medit & $\mathrm{Sr}, \mathrm{At}, \mathrm{Or}$ \\
\hline Lagurus ovatus L. subsp. ovatus & T scap & Euro-Medit & $\mathrm{Sp}, \mathrm{Sr}, \mathrm{At}, \mathrm{Or}$ \\
\hline Lolium multiflorum Lam. & T scap & Euro-Medit & Or \\
\hline Lolium rigidum Gaudin subsp. rigidum & T scap & Paleosubtrop & $\mathrm{Sp}$, Or \\
\hline Melica ciliata L. subsp. ciliata & H caesp & Euro-Medit.-Turan & $\mathrm{Sr}, \mathrm{At}$ \\
\hline Monerma cylindrica (Willd.) W. Greuter & T scap & Euro-Medit & $\mathrm{Sr}, \mathrm{At}$ \\
\hline Parapholis filiformis (Roth) C.E. Hubbard & T scap & Medit.-Atl & $\mathrm{Or}$ \\
\hline Parapholis incurva (L.) C.E. Hubbard & T scap & Medit.-Atl & $\mathrm{Sp}, \mathrm{Sr}, \mathrm{At}, \mathrm{Or}$ \\
\hline Parapholis marginata Runemark & T caesp & E-Medit & $\mathrm{Sr}$ \\
\hline Paspalum distichum $\mathrm{L}$. & G rhiz & Subcosmop & Sp \\
\hline Phalaris minor Retz. & T scap & Paleosubtrop & $\mathrm{Sr}, \mathrm{Or}$ \\
\hline Phalaris paradoxa $\mathrm{L}$. & T scap & Steno-Medit & Or \\
\hline Phragmites australis (Cav.) Trin. ex Steudel & Hyd & Subcosmop & $\mathrm{Sp}, \mathrm{Sr}, \mathrm{At}, \mathrm{Or}$ \\
\hline Piptatherum coerulescens (Desf.) P. Beauv. & H caesp & Steno-Medit & At \\
\hline $\begin{array}{l}\text { Piptatherum miliaceum (L.) } \\
\text { Cosson subsp. miliaceum }\end{array}$ & H caesp & Medit.-Turan & $\mathrm{Sp}$, Or \\
\hline Poa trivialis L. subsp. trivialis & H caesp & Eurasiat & $\mathrm{Sr}, \mathrm{At}$ \\
\hline Polypogon maritimus Willd. subsp. maritimus & T caesp & Steno-Medit.-Macar & $\mathrm{Sp}, \mathrm{Sr}$ \\
\hline Polypogon monspeliensis (L.) Desf. & T scap & Paleosubtrop & $\mathrm{Sp}, \mathrm{Sr}, \mathrm{At}, \mathrm{Or}$ \\
\hline Polypogon viridis (Gouan) Breistr. & H caesp & Paleosubtrop & $\mathrm{Sp}$ \\
\hline Puccinellia distans (Jacq.) Parl. subsp. distans & H caesp & Paleotemp & $\mathrm{Sp}, \mathrm{Sr}, \mathrm{At}$ \\
\hline Puccinellia distans subsp. limosa (Schur) Jáv. & H caesp & SE-Europ. & $\mathrm{Sp}$ \\
\hline Puccinellia festuciformis (Host) Parl. & H caesp & Steno-Medit & $\mathrm{Sp}, \mathrm{Sr}, \mathrm{At}$ \\
\hline Rostraria cristata (L.) Tzvelev & T caesp & Paleotemp & $\mathrm{Sp}, \mathrm{Sr}, \mathrm{Or}$ \\
\hline Tripidium ravennae (L.) H. Scholz & H caesp & Medit.-Turan & $\mathrm{Sp}$ \\
\hline Sphenopus divaricatus (Gouan) Reichenb. & T scap & Medit.-Turan & Or \\
\hline Sporobolus virginicus (L) Kunth & G rhiz & Subtrop & $\mathrm{Sp}, \mathrm{At}$ \\
\hline $\begin{array}{l}\text { Vulpia fasciculata (Forskål) Samp. } \\
\text { Iridaceae }\end{array}$ & T caesp & Medit.-Atl & $\mathrm{Sp}$ \\
\hline
\end{tabular}




\begin{tabular}{|c|c|c|c|}
\hline & Life form & Chorological type & Distibution \\
\hline $\begin{array}{l}\text { Morea sisyrinchium (L.) Ker Gawl. } \\
\text { Juncaceae }\end{array}$ & G rhiz & Steno-Medit & Or \\
\hline Juncus acutus L. subsp. acutus & H caesp & Euro-Medit & $\mathrm{Sp}, \mathrm{Sr}, \mathrm{At}, \mathrm{Or}$ \\
\hline Juncus articulatus L. & G rhiz & Circumbor & Sp, At \\
\hline Juncus bufonius L. & T caesp & Cosmop & $\mathrm{Sr}, \mathrm{At}, \mathrm{Or}$ \\
\hline Juncus gerardi Loisel subsp. gerardi & G rhiz & Circumbor & $\mathrm{Sr}$ \\
\hline Juncus heldreichianus Marsson ex Parl. & H caesp & E-Medit & Sr, At \\
\hline Juncus hybridus Brot. & T caesp & Medit.-Atl & Sp, At \\
\hline Juncus inflexus L. & H caesp & Paleotemp & At \\
\hline Juncus littoralis C.A. Mayer & H caesp & Medit.-Turan & At \\
\hline Juncus maritimus Lam. & G rhiz & Subcosmop & $\mathrm{Sp}, \mathrm{Sr}, \mathrm{Or}$ \\
\hline $\begin{array}{l}\text { Juncus subulatus Forsskål } \\
\text { Juncaginaceae }\end{array}$ & G rhiz & S-Medit & $\mathrm{Sp}, \mathrm{Sr}, \mathrm{At}$ \\
\hline $\begin{array}{l}\text { Trigloghin bulbosa subsp. barrelieri } \\
\text { (Loisel.) Rouy }\end{array}$ & G bulb & Steno-Medit & Or \\
\hline Orchidaceae & & & \\
\hline $\begin{array}{l}\text { Ophrys fusca Link } \\
\text { Potamogetonaceae }\end{array}$ & G bulb & Steno-Medit & Or \\
\hline Potamogeton pectinatus L. & Hyd & Subcosmop & $\mathrm{Sr}$ \\
\hline $\begin{array}{l}\text { Potamogeton pusillus } \mathrm{L} . \\
\text { Ruppiaceae }\end{array}$ & Hyd & Subcosmop & $\mathrm{Sr}$ \\
\hline $\begin{array}{l}\text { Ruppia maritima } \mathrm{L} . \\
\text { Sparganiaceae }\end{array}$ & Hyd & Cosmop & Or \\
\hline $\begin{array}{l}\text { Sparganium erectum subsp. neglectum } \\
\text { (Beeby) Schinz \& Thell. }\end{array}$ & Hyd & Eurasiat & $\mathrm{Sp}$ \\
\hline Typhaceae & & & \\
\hline Typha domingensis (Pers.) Steudel & Hyd & E-Medit & $\mathrm{Sp}, \mathrm{Sr}, \mathrm{At}$ \\
\hline $\begin{array}{l}\text { Typha latifolia } \mathrm{L} . \\
\text { Zannichelliaceae }\end{array}$ & Hyd & Cosmop & $\mathrm{Sp}$ \\
\hline Althenia filiformis Petit & Hyd & Steno-Medit.-Occid & Or \\
\hline
\end{tabular}


Complete list of the syntaxa quoted in the text.

Aeluropetum littoralis (Prodan 1939) Şerbănescu 1965

Alkanno tinctoriae-Maresion nanae Rivas Goday ex Rivas Goday \& Rivas-Martinez 1963 corr.

Díez-Garretas, Asensi \& Rivas-Martinez 2001

Ammophiletea Br.-Bl. et Tx. ex Westhoff et al. 1946

Arthrocnemion glauci Rivas-Martínez \& Costa 1984

Arthrocnemo glauci-Halocnemetum strobilacei Oberdorfer 1952

Arthrocnemetum glauci Br.-Bl. 1933

Arthrocnemo-Halocnemetum strobilacei Oberdorfer 1952

Bolboschoenetum maritimi Eggler 1933

Cakiletea maritimae Tx. et Preising ex Br.-B1. et Tx. 1952

Caricetum divisae Br.-B1. 1931

Cutandietalia maritimae Rivas-Martinez, Díez-Garretas \& Asensi in Rivas-Martinez et al.

2002 Eryngio-Sporoboletum virginici Géhu et Uslu 1989

Festuco-Puccinellietea Soó 1968

Halimiono-Arthrocnemetum glauci Istanbullouglou 2004

Halocnemetum strobilacei Oberdorfer 1952 em. Géhu 1994

Juncetum acuti Molinier \& Talon 1969

Juncetea maritimi R. Tx. et Oberd. 1958

Juncetum maritimi (Rübel 1930) Pignatti 1953

Juncetum maritimo-acuti Horvatić 1934

Juncetum subulato-maritimi Gradstein \& Smittenberg 1977

Limonietalia Br.-Bl. \& O. de Bolòs 1958

Myriophyllo-Potametum Soó 1943

Nerio-Tamaricetea Br.-B1. et O. de Bolós 1958

Phragmitetum communis Schmale 1939

Phragmito-Magno-Caricetea Klika in Klika et Novák 1941

Potamo pectinati-Myriophylletum spicati Rivas Goday 1964 corr. Conesa 1990

Saginetea maritimae Westhoff \& al. 1962

Salicornietea fruticosae Br.-Bl. et R. Tx. ex A. et O. de Bolòs 1950

Salicornietum radicantis Br.-Bl. 1933

Salsolo kali-Cakiletum maritimae Costa et Mansanet 1981 corr. Rivas-Martinez, Costa \& Loidi 1992

Schoenoplectetum tabernaemontani Soó 1947

Scirpo-Juncetum subulati Géhu, Biondi, Géhu-Frank \& Costa 1992

Spergulario marinae-Salicornietum europeae Bueno \& F. Prieto in Bueno 1997 corr. Bueno 1997

Stellarietea mediae R.Tx. \& al. ex von Rochow 1951

Thero-Brachypodietea Br.-Bl. ex A. de Bolós y Vayreda 1950

Thero-Salicornietea (S. Pignatti 1953) R. Tx. in R. Tx. et Oberd. 1958

Thero-Suaedion Br.-Bl. in Br.-B1., Roussine \& Nègre 1952 